\title{
A Review of Sludge-to-Energy Recovery Methods
}

\author{
Jumoke Oladejo ${ }^{1}$, Kaiqi Shi ${ }^{1, *}$, Xiang Luo ${ }^{1}$, Gang Yang ${ }^{1}$ and Tao $\mathrm{Wu}^{1,2, * \mathbb{C}}$ \\ 1 New Materials Institute, The University of Nottingham, Ningbo 315100, China; \\ jummyoladejo@gmail.com (J.O.); Xiang.luo@nottingham.edu.cn (X.L.); \\ Gang.YANG@nottingham.edu.cn (Y.G.) \\ 2 Department of Chemical and Environmental Engineering, The University of Nottingham, \\ Ningbo 315100, China \\ * Correspondence: kaiqi.shi@nottingham.edu.cn (K.S.); tao.wu@nottingham.edu.cn (T.W.); \\ Tel.: +86-186-5826-1515 (K.S.)
}

Received: 17 November 2018; Accepted: 18 December 2018; Published: 25 December 2018

check for updates

\begin{abstract}
The increasing volume of sewage sludge from wastewater treatment facilities is becoming a prominent concern globally. The disposal of this sludge is particularly challenging and poses severe environmental hazards due to the high content of organic, toxic and heavy metal pollutants among its constituents. This study presents a simple review of four sewage to energy recovery routes (anaerobic digestion, combustion, pyrolysis and gasification) with emphasis on recent developments in research, as well as benefits and limitations of the technology for ensuring cost and environmentally viable sewage to energy pathway. This study focusses on the review of various commercially viable sludge conversion processes and technologies used for energy recovery from sewage sludge. This was done via in-depth process descriptions gathered from literatures and simplified schematic depiction of such energy recovery processes when utilised for sludge. Specifically, the impact of fuel properties and its effect on the recovery process were discussed to indicate the current challenges and recent scientific research undertaken to resolve these challenges and improve the operational, environmental and cost competitiveness of these technologies.
\end{abstract}

Keywords: sewage; anaerobic digestion; combustion; pyrolysis; gasification

\section{Introduction}

The rapidly increasing population and urbanization growth has resulted in higher demands on finite resources such as land space, water, food and energy. It has also intensified environmental challenges, which include pollution and waste management issues. These issues are quite detrimental to the global goal of sustainable development and hence, have ignited global interest in sustainable strategies for energy utilization, production and waste management. A direct and an easily overlooked consequence of the increasing waste globally is the escalating volume of urban wastewater, especially sewage sludge. Sewage sludge can be described as any solid, semi-solid or liquid waste generated from a wastewater treatment facility. This wastewater can be sourced from municipal, commercial or industrial processes. The physical properties (low ratio of solid to liquid matter) of sewage requires thickening and mechanical dewatering to facilitate transportation and logistics during the treatment processes. These processes help increase the solid particles concentration in sludge to $\sim 10-25 \mathrm{wt} \%$ from the original predominantly liquid ( $<3 \mathrm{wt} \%$ solid) state [1-4]. In water treatment facilities, the preliminary treatment of the raw sewage is done such as initial straining of received sludge for removal of large particles such as sand, grit and stone. This is followed by the settling of the sewage in sedimentation tanks using gravitational force which enables the formation and removal of slurry sludge at the bottom of such tanks [2,5]. This marks the point of primary sludge generation. The solid phase in sludge is made up of an in-homogenous mix of proteins, carbohydrates, 
oils, inorganic matters and micro-organisms. This mixture of organic, inorganic and living organisms results in an unstable, volatile and putrid matter with toxic elements [3]. Consequent treatments after this are mostly biological (composting or digestion), physical (e.g., pressure, heat, vibration, microwaves) or chemical (oxidations, alkalinity adjustments) methods aimed at stabilising the organic matter (destruction of pathogens, odour elimination and reduction of volatile contents) contained in the primary sludge in order to improve the quality of effluent, maximize nutrient recovery and/or for safer disposal. The product of this stabilisation process could be referred to as secondary sludge if it undergoes further biological processes [2,6-8]. Anaerobic digestion is an example of such stabilisation technique whose secondary sludge can be used as fertilizer and incorporated with energy recovery capabilities by harnessing the produced biogas from the digester [9]. With the exception of initial pre-treatments such as drying, the utilisation of thermal treatment methods for stabilisation normally results in the production of char and/or ash as the output residues, rather than sludge. Unfortunately, the variety of sewage types, their origins and the production/treatment process leads to variations in the properties of the sludge. Also, the additional resource, energy and cost implication incurred from the treatment and appropriate disposal of this waste has led to an increase in sea dumping, particularly in developing continents like Africa and Asia [2,10]. For example, approximately $85 \%$ of sludge produced in China is currently improperly dumped into water bodies [2]. Alternative disposal methods used in developed countries that have imposed legal implications for improper dumping include landfilling, composting, incineration and land reclamation applications.

Recently, the annual sewage sludge production has been estimated at 10 million tons (dry matter), 20 million tons and 49 trillion litres in Europe, China and the United States, respectively, and further increases have been projected with economic and population growth [1,2]. Such a predicted increase in sludge production, environmental cost of improper disposal, shortage of landfills, stricter environmental regulations and renewed interest in the circular economy is an indication of the need for improving the current sewage sludge disposal practices worldwide. Apart from the ecological degradation caused by improper disposal of sludge, the disposal techniques like landfills, composting or storage are fast becoming unsustainable from an environmental perspective due to the shortage of land for landfill sites and rising environmental and health concerns with regards to the suitability of sludge constituents (pathogens, heavy metals and organic pollutants) in agricultural applications [7,11-14]. Still, the most predominant usage of recovered sludge is for agricultural use such as fertilizer. However, due to the increasingly restrictive environmental standards because of its high organic, phosphate and heavy metals contents, the requirements for biological routes such as anaerobic digestions, as well as thermal reactors such as incinerators for treatment, stabilisation and processing of sludge in any resource or energy recovery applications has increased [1]. Sustainability measures have increased focus on the recovery and reuse of sludge after treatment to reduce landfill requirements, environmental footprint and with lesser impact on the land, groundwater and food supply. All of which necessitates further development of sewage sludge management dynamics [3]. Such processing is aimed at the recovery and usage of sludge derived products such as raw rare metals, phosphorus, ash, chemicals and organic fuels. All of these requirements require better policies and enforcements and improved technologies for the processing, treatment, recovery and final disposal in the sludge utilisation chain. In the meantime, well-established processes remain quite limited in their capacities and capabilities to appropriately and economically meet all legal and environmental safety standards. This creates an engineering and design challenge associated with sewage sludge recycling technologies with focus on energy recovery from such wastes.

Owing to its volatile organic contents, which ranges from $21-48 \%$, the energy content of dried sewage sludge reported in past literature varies between $11.10-22.10 \mathrm{MJ} / \mathrm{Kg}$ which indicates comparable and/or higher calorific values in comparison to lignite and various biomass samples $[2,15]$. This heating value is one of the core determinants of the suitability of sludge as a solid fuel, as well as the need to effectively eliminate the high organic matter from sludge before disposal. Consequently, energy recovery from sludge is regarded as the most attractive methods for utilising the increasing 
quantity of sludge for eliminating volatile organic matter and reducing waste volume with possibility of recovering nutrients and/or metals. Most of these energy recovery technologies are not new as they have been developed commercially for other fuel types, however differences in the physical and chemical properties of sludge presents unique technical challenges which influences the energy recovery process and reactions. This is particularly relevant to thermochemical processes used for solid fuels such as coal and biomass with lower moisture, nitrogen and heavy metal content. For successful deployment of sludge to energy recovery platform worldwide, these factors must be considered carefully with sustainable and practical solutions to prominent challenges. This reinforces the need for further research into the viability and effectiveness of such conversion technologies to ensure commercialisation potential. While anaerobic digester and incinerator are traditionally adopted technologies for this waste, recent development have instigated new treatment methods and thermochemical technologies for improving energy efficiency with various optimistic commentaries on the commercial readiness of these technologies. Especially with growing interest in waste to energy technologies, the fondness for this concept might be adequate bias on the practicality and sustainability of such systems. Currently, only a handful of papers have reviewed energy recovery as a sludge treatment method with none evaluating current gaps in practices and its implication for sustainability $[1,2,16]$.

This review work examines the fundamentals of various commercially viable energy recovery technologies that can be utilised sewage sludge. The detailed assessment of the impact of sludge properties, technological challenges and recent research directions to improve the energy recovery routes for the extracting high-value products (heat, power and synthesis gas) was discussed and summarised. This would also include an in-depth discussion on the properties of using sludge as feedstock individually or co-utilised with other solid fuels and the importance of pre-processing such as drying on the thermochemical processing yield. Finally, this paper deliberates on the briefly on the readiness of these energy recovery methods from a social, technological, environmental and economic perspective to gauge its commercial deplorability worldwide as sludge processing is a global concern. Furthermore, scientific literatures published in the last 10-15 years were reviewed and tabulated to highlight research themes been done for overcoming these challenges and increasing energy recovery. The references cited in this review paper are globally sourced and provide scientific and technological insights useful in obtaining an effective, economically viable and environmentally safe energy recovery technique for sewage sludge processing. Anaerobic digestion, combustion, pyrolysis and gasification are the only technologies analysed in this work. In addition, the identification of influencing factors and some barriers to the sustainable development of these technologies for sludge-to-energy was highlighted with focus on treatment technologies, energy and resource recovery. This review is aimed at encouraging further research work that would aid in scaling up and improving these technologies for ensuring affordability, acceptability and environmental sustainability.

\section{Sludge-to-Energy Recovery Methods}

The importance of energy recovery in contemporary waste management practices remains assured due to its impact on global waste minimization, resource optimization and alternative energy generation. The focus energy conversion technologies have been highlighted in Figure 1, which shows the conversion pathways of sludge to syngas, liquid fuel, chemicals, heat and/or electricity. 


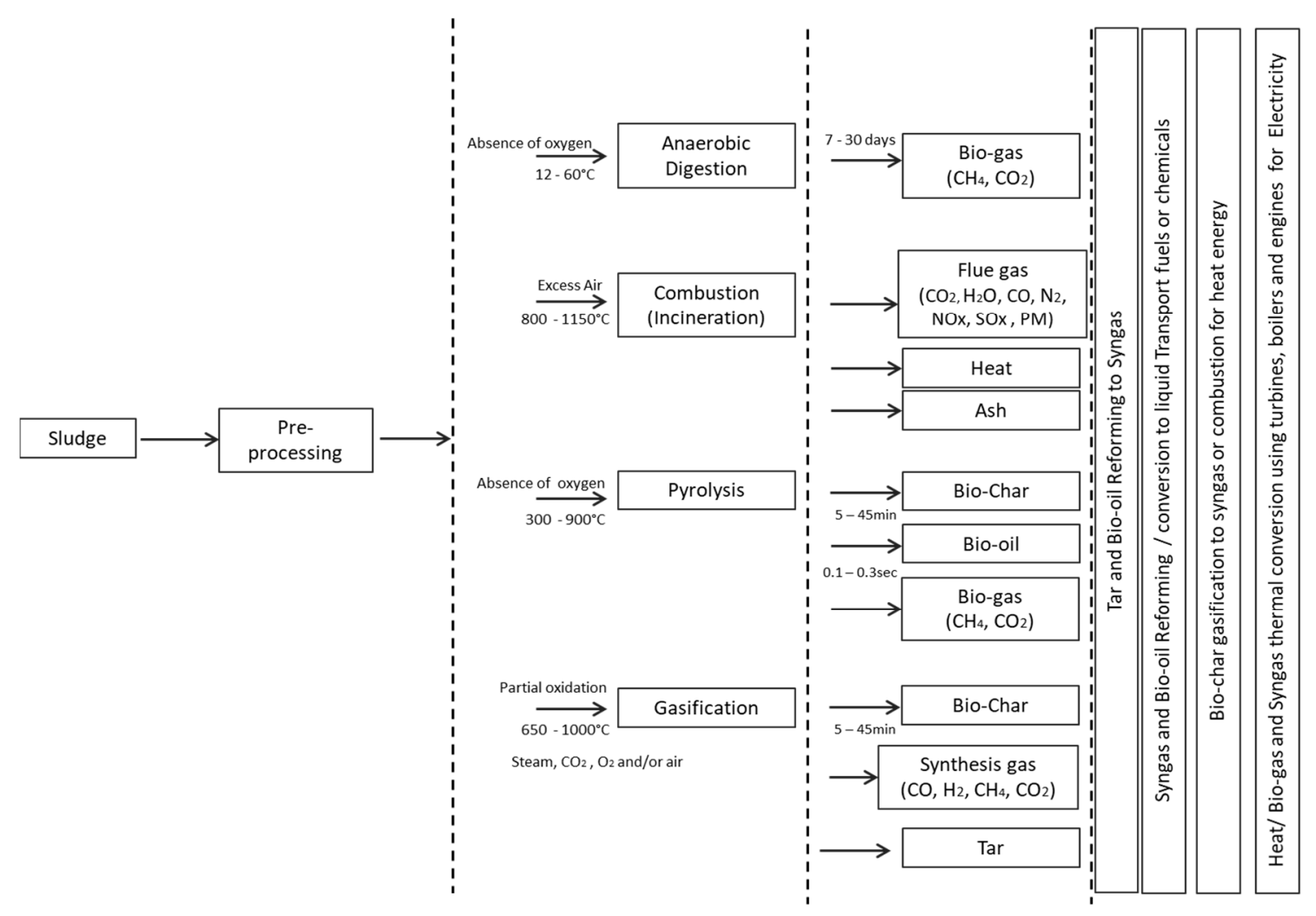

Figure 1. Potential Sludge-to-Energy Recovery Routes (drawn from information gathered from [1,2,4-6]).

Anaerobic digestion is a biological conversion method which is widely used due to its low cost and ability to utilize organic waste with high moisture content without reducing the high calorific value of the produced biogas (combination of methane and carbon dioxide). The biogas obtained from the digester can be cleaned and further upgraded to produce bio-methane which can be a direct substitute for natural gas or the biogas can be converted to heat and electricity via cogeneration using thermal reactors. Biochemical processes traditionally occur in an inert environment at mesophilic temperatures for sludge stabilization with process residues used for agricultural purposes [2,17]. However, the reaction time is long with duration ranging from 7 days to 5 weeks and the conversion efficiency of organic matter is low with $40-70 \%$ of organic constituents unconverted after reaction completion. This results in digested sludge with poor biodegradability and high organic content diverted for agricultural applications which is inappropriate.

On the other hand, thermochemical conversion routes such as combustion, pyrolysis and gasification are characterised by shorter reaction times which range from seconds to min. Unfortunately, these processes require sludge with lower moisture content and drying of sludge requires enormous energy inputs. The rapid and controlled decomposition of $\geq 80 \%$ of the organic matter in inert, partially oxidizing or oxidizing atmospheres is one of the main benefits of these thermal processes in comparison the anaerobic digestion [17]. Although, the cost of thermal technologies are still significantly higher, as mentioned previously, incineration is another prominent process currently in use for sewage sludge management but the traditional practice was not intended for energy recovery but for waste volume reduction and harmful elements destruction $[18,19]$. The incorporation of heat recovery converts a traditional incinerator into a typical combustion system which harnesses heat from the flue gas derived after the complete oxidation of organic matter at high temperatures $\left(800-1150{ }^{\circ} \mathrm{C}\right)$. The heat extracted is used for heating fluid (typically water) which can be used directly by heating or for generating electricity via a steam turbine. In contrast to combustion, pyrolysis takes place in completely inert atmosphere (devoid of oxygen) at moderate to high temperature $\left(300-900{ }^{\circ} \mathrm{C}\right)$ to produce pyrolytic oil, biochar and non-condensable gases $\left(\mathrm{CO}, \mathrm{H}_{2}, \mathrm{CO}_{2}, \mathrm{CH}_{4}\right.$ and light hydrocarbons) [7,19]. The operating 
temperature, heating rate and residence time greatly impacts the product distribution and energy content of pyrolytic products. Bio-oil can be upgraded and used as liquid fuel or reformed to synthesis gas $\left(\mathrm{CO}\right.$ and $\left.\mathrm{H}_{2}\right)$ for chemical production, while the biochar, non-condensable gases and bio-oil can also be used solid, gaseous and liquid fuels for electricity and heat generation via combustion. Alternatively, biochar can be used in adsorption or catalyst applications. Lastly, gasification involves the thermochemical conversion of organic compounds via partial oxidation (oxidiser lower than stoichiometric requirements) at high temperatures $\left(650-1000^{\circ} \mathrm{C}\right)$ for maximising gaseous products $\left(\mathrm{CO}, \mathrm{H}_{2}, \mathrm{CO}_{2}\right.$ and light hydrocarbons), particularly synthesis gas $\left(\mathrm{CO}\right.$ and $\left.\mathrm{H}_{2}\right)[2,20]$. The energy content of the product gas varies from 4-28 MJ/Nm depending on the gasifying agent and temperature. The derived gas can be routed to variety of end usages such as direct combustion for heat and electricity generation using a combined cycle gas turbine or further upgrading of synthesis gas into liquid fuels or chemicals via gas to liquid processes such as Fischer-Tropsch synthesis.

As these processes would be discussed in more details in later sections, the dependence of the energy recovery efficiency on the sludge properties requires a brief discussion. As described by past studies on sludge $[2,15,21,22]$, sludge is primarily made up of: (i) water content, which is as high as $98 \%$ in the liquid phase and removed primarily by mechanical dewatering to obtain up to $25 \mathrm{wt} \%$ solid matter in sticky phase sludge. Further removal can be done via thermal drying to obtain $<10$ $\mathrm{wt} \%$ moisture content in dried granular sludge (ii) non-toxic organic compounds which account for up to $48 \%$ of the dry solid and are derived mostly from plant sources (characterised by high volatile matter content). These compounds account for $\sim 60 \%$ of the energy content in the raw wastewater with a heating value of $11.10-22.10 \mathrm{MJ} / \mathrm{Kg}$, (iii) biological pollutants such as micro-organisms and pathogens, (iv) non-toxic inorganic compounds, e.g., aluminium-, silicon-, iron- and calcium-containing compounds, (v) toxic inorganic compounds such as zinc, nickel, mercury, chromium and, arsenic, mainly from industrial waste and corroded sewers. These compounds have higher concentrations in sludge compared to other solid fuels, (vi) toxic organic pollutants like dioxins and polycyclic aromatic hydrocarbons, and (vii) phosphorus and nitrogen containing compound sourced from peptides, proteins, sugars and fatty acids. All these constituents change physically and chemically with each energy recovery method. Changes include reduction in organic content, fluctuations in pollutants stability and toxicity, release of volatiles from solid fuels, densification of sludge and transformation of sludge into mainly inorganic compounds. Such changes must be appropriately monitored during all reaction stages.

Although, out of scope for this work, bioelectrochemical systems which converts organic matter into hydrogen/ methane/valuable chemical products(e.g., acetate, alcohols and fatty acids) by using microbial electrolysis cells and/or electricity using microbial fuel cell via electrochemical reduction are examples of high potential and promising sludge-to-energy technologies $[20,23]$. These system present a recent concept in energy recovery which may not require the use of expensive catalysts or rare metals. Concept of microbial electro-synthesis is still very novel and already has high prospect in various applications due to alternative materials for electrodes, separators, and catalyst, as well as unique system designs. With various technical challenges such as low power density, low conversion and yield rates and low catalytic capability which affects successful up-scaling, this system is currently considered to be expensive and in infancy development phase. Thorough review of such concepts has been done by others $[20,23]$. Nonetheless, research in this field is increasing exponentially and the future prospect of these biotechnologies remain optimistic, particularly with the development of cheap bio-cathodes and the elimination of external electricity requirements for driving the process. Another innovative concept is the integrated bio-refinery approach which involves the extraction of value added products and nutrients from sludge with emphasis on amino acids, proteins, bio-pesticides, fatty acids, phosphorus, bio-flocculants, enzymes, bio-plastics and bio-fuels [24-27]. Even though this concept is in its early stages, it is aimed at producing high value chemicals, liquid transportation fuels-bio-diesel and bioethanol—synthesis gas, heat and electricity. Hence, it has the potential for optimal extraction and utilisation of resources from waste streams. It is mostly integrated with anaerobic digestion, 
biological processes and thermal processes for production of bio-products, bio-chemicals and bio-fuels. However, this is currently a research field which requires further optimization in terms of operation parameters, cost and the quality of the extracted products. The biorefinery concept has recently been critically reviewed by Raheem et al. [16] and others [24,28]. Scalability, supply chain feasibility are the major hindrances to its development. Nonetheless, as this review work is focused on commercially deployable technologies that could help tackle sludge by transforming it into energy, bioelectrochemical systems and biorefineries are not further evaluated in this work.

\subsection{Pre-Processing of Sludge}

The constituents of sludge are made of blends of organic matters such as carbohydrates, proteins, fats and oils, a range of microorganisms (both living and dead), and inorganic elements which are characterized by high energy content. Nevertheless, the properties of sewage sludge are highly variable and dependent on its origin, wastewater treatment system, environmental requirements, seasonal variations and production processes such that simple processing such as drying can easily improve its organic contents and calorific value significantly. This makes the variability in sludge's chemical composition more extreme in comparison with traditional biomass and coal samples. In addition to this, sludge has been detected to compose of high water content, toxic inorganics such as silver, cadmium, zinc, cobalt, chromium, copper, nickel, lead, mercury, and arsenic, organic pollutants and pathogens and microbiological pollutants [4-6]. These heavy metals are mostly pollutants from physiochemical and biological processes such as industrial waste, corrosion in pipelines, food, medicine, textile materials and cosmetics.

The proximate analyses of sludge is such that the volatile matter of biomass is higher while coal has lower volatile content in comparison to sludge. Also, the fixed carbon of coal and biomass is higher than that of sludge as established by past works [2,6]. Nonetheless, the ash content (mostly aluminium, calcium, iron, magnesium, sodium, phosphorus, silicon and titanium) of sludge is higher than that of biomass and coal due to its high inorganic content [7]. Similarly, the ultimate analyses of sludge reveal higher nitrogen (from protein and peptides), higher hydrogen and comparable carbon contents to lignite and biomass. The sulphur and oxygen content remain higher than biomass but comparable to that of lignite. Wet sludge has approximately $98 \mathrm{wt} \%$ moisture content and after mechanical dewatering processes, free water and some of the interstitial water can be removed, leaving about $73-84 \%$ of the water content. Irrespective of this dewatering process, the remnant moisture (mostly vicinal water) might require the application of thermal energy for rapid drying. The use of heat can reduce the moisture to very small content $\sim 5.6 \%$ which is mostly chemically bonded water from inorganics such as calcium or aluminium hydroxides $[7,8]$.

As mentioned previously, the high moisture content in wastewater would require removal through various dewatering processes. The most widely adopted method for obtaining primary sludge involves the coagulation, flocculation and sedimentation process such that coagulants are used to neutralize the charges of dispersed solid particles in wastewater and ease the formation of microflocs which are submicroscopic suspended particles made of dust, organic matter, earth particles, etc., stuck together after collision when coagulant is mixed with wastewater [2,9]. After coagulation, flocculation involves a slow mixing stage (with or without coagulants aids) intended to maximise collision contact and bind various microflocs to increase the size and become visible macroflocs of greater size and strength. Afterwards, sedimentation is used to remove the suspended particles from the water by the use of settling basins and mechanical systems for continuous removal of solids. As these flocs are heavier than water, sedimentation allows the falling down of suspended macroflocs against a barrier using centrifugal forces, electromagnetism and gravitational forces. This stage is the primary sludge formation point which still has about $70-75 \%$ moisture content. After this, other sludge dewatering and drying technologies such as belt presses, centrifuges, direct dryers and/or indirect dryers vacuum filters are used for the removal of the bulk of fluids contained in the primary sludge. Most drying techniques involve the use of thermal energy which can be naturally sourced using 
solar energy or the use of conventional energy intensive dryers (convection, conduction and hybrid dryers). The use of multiple low temperature heat sources via condensing heat exchangers for staged heating was also investigated for maximising thermal energy usage and improving the efficiency of the energy recovery process [29]. Most natural methods would utilise aeration techniques which would still require some form of energy consumption as well as more time for the completion of drying. The drying of fuels for vaporising their moisture content before further thermal processing has been well established for biomass and low rank coals such that the thermal process is designed to use up waste heat energy from the fuel thermal processing for the initial drying of the fuels. However, the drying process involves additional energy and operating costs $[9,10]$. The importance of drying for energy recovery from sludge is for the physical transformation of the waste material from wet matter into granular feedstock that can be easily handled and further use in most thermal processes.

\subsection{Anaerobic Digestion}

Anaerobic digestion is a biological process that occurs in an inert environment for the conversion of organic compounds into biogas by the use of microorganisms. The use of naturally occurring bacteria for biodegradation involves a series of biochemical stages including hydrolysis, acidogenesis (fermentation), acetogenesis and methanogenesis.

These metabolic stages are used for mass and volume reduction of the sludge while the organic contents are converted to biogas by the pathogens. The hydrolysis stage involves the conversion of the non-toxic organics into simple sugars, fatty acid and amino acids. Afterward, the acidogenesis and acetogenesis stage aids the fermentation of the hydrolysis products into acetate, carbon dioxide and hydrogen gas which are further converted to methane through methanogenesis [11]. Hence, each stage affects the performance of the digester, as depicted in Figure 2. This technique is adopted globally as the technologically matured and cost effective process used for stabilizing sludge before final disposal and the simplified schematic is represented in Figure 3. The dewatered sludge can be used directly in this energy recovery method and fed into the digester, but as mentioned previously, the high organic content of the digestate (digested sludge) has increased focus on the utilisation of pre-/inter- and/or post-treatment methods for maximising energy recovery and aiding the conversion of volatile organic solid in the digester. The digester is simply an air-tight tank where micro-organisms are aided by physical, biological or chemical catalysts (heat, enzymes and/or solvents) for the decomposition of organic matter. The effluent gas is biogas which is made up of $60-70 \%$ methane, $30-40 \%$ carbon dioxide and trace elements of other gases $\left(\mathrm{H}_{2} \mathrm{~S}\right)$ with total calorific value of up to $28.03-38.92 \mathrm{MJ} / \mathrm{Nm}^{3}[2,20,30]$. The biogas with its high methane content can be recovered for heat and electricity production using boilers, turbines and generators or alternatively upgraded for use as bio-methane. Studies by Aryal and Kvist [30], revealed the potential of upgrading biogas to $97.55 \%$ methane by the use of water scrubbers. This increases the calorific value of the biogas from 28.03 to $51.31 \mathrm{MJ} / \mathrm{Nm}^{3}$. Simultaneously, the remnant after this digestion process has high nutritional contents (phosphorus, potassium and nitrogen) which can be used as compost and/or fertilizers for agricultural and soil reclamation purposes if it conforms with environmental standards. In practice, a unit can consist of multiple digesters forming multi-stage systems to enhance gas recovery with various treatment methods used at each stage. 


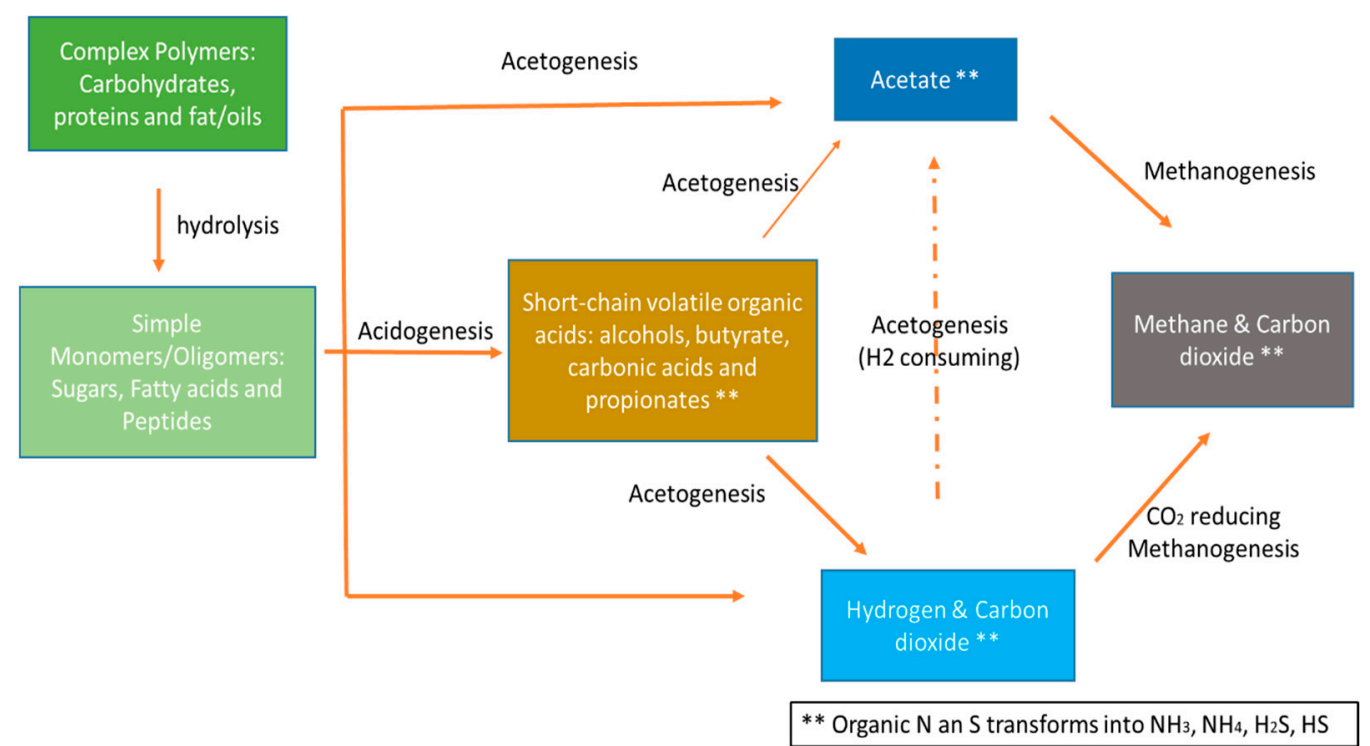

Figure 2. Biological Processes during Anaerobic Digestion of Sludge (based on information from [11]).

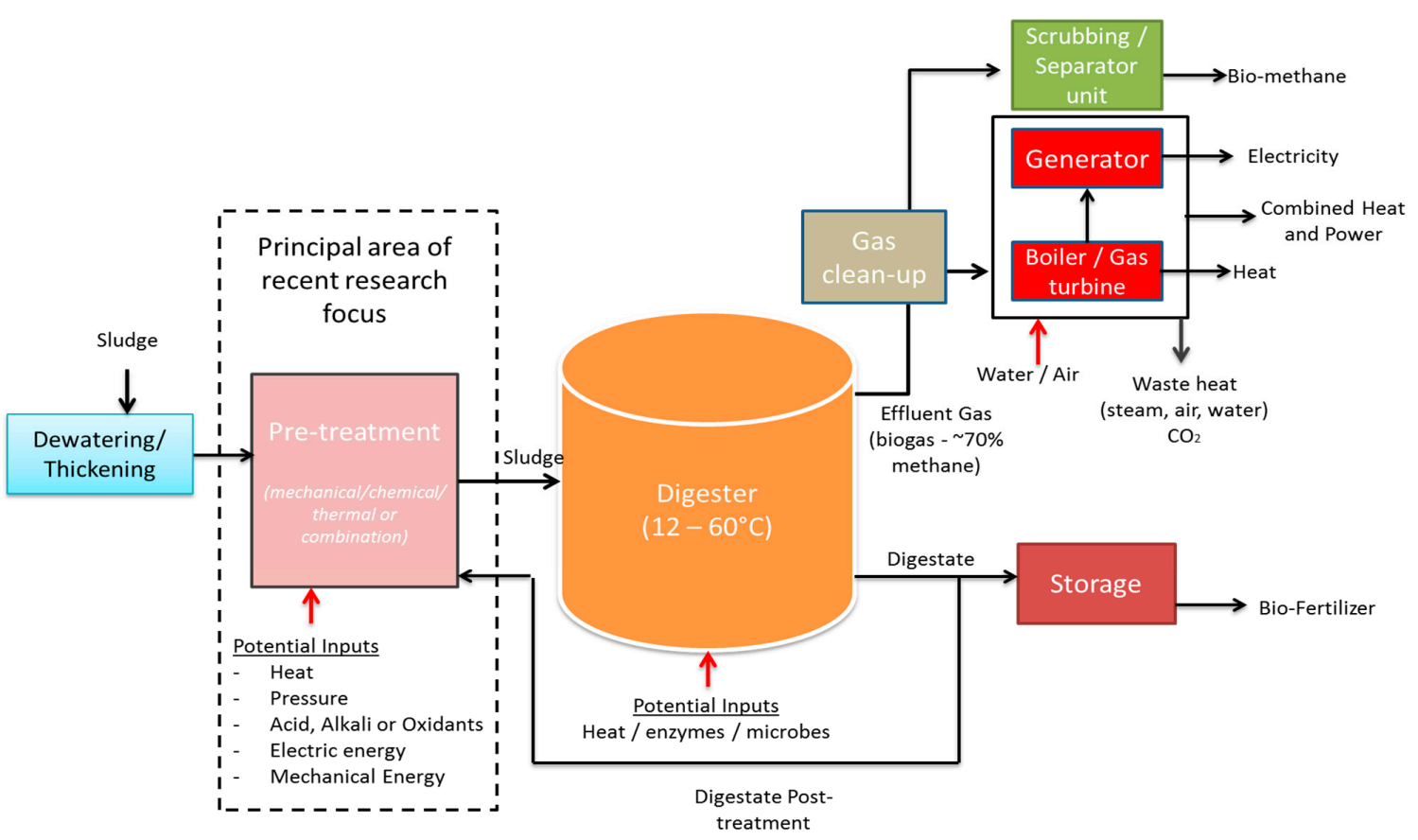

Figure 3. Schematic representation of the anaerobic digestion of sludge.

The potential of using this waste derived energy in the wastewater treatment plan has the potential of offsetting about $50 \%$ of the operational energy used in such facilities [10,12]. Alternatively, the energy can be used at other sources or sold to the grid. The utilization of this biogas contributes to the reduction of greenhouse gases emissions which occurred previously from the flaring or non-utilisation of the derived biogas as traditionally adapted. Nonetheless, this method of processing has a huge limitation with the long reaction time required and the need for suitable reaction conditions for the microorganism development which makes its cost effectiveness and profitability limited to large treatment plants.

The enhancement of the biogas yield and quality (methane to $\mathrm{CO}_{2}$ fraction), reduction of reaction time and implementation of better control strategies are the main factors being investigated for improving process efficiency and maximising energy recovered. Still, temperature remains one of the most decisive considerations that influence the quality and quantity of the biogas and its reaction time (digestion rate). Presently, digestion reactions occur within $12-60{ }^{\circ} \mathrm{C}$ depending on the reactor 
environment-landfill, sediments or anaerobic digesters [13]. The methane yield obtained from sludge varies between $80-377 \mathrm{~mL} \mathrm{CH}_{4}$ /g volatile solid depending on the feedstock, the number of digestion days, the process temperature and the pre-treatment methods used $[14,17,31]$. The use of chemical, mechanical and thermal pre-treatments methods to enhance the anaerobic conversion and improve anaerobic digestion of sludge has been widely adopted. Chemical pre-treatments mainly involve the use of strong reagents such as acid and alkali and oxidants for adjusting the $\mathrm{pH}$ of the sludge such that the yield of biogas is maximised by increasing the soluble organic fraction. Mechanical pre-treatments involve the use of mechanical vibration such as ultra-sonication for the disruption of the organic solid in the sewage sludge. Physiochemical pre-treatment such as microwave radiation quickens biological, chemical and physical processes due to heat and extensive collisions from the vibration of molecules and ion movement. Thermal hydrolysis involves the use of heat and/or pressure treatment for improving sludge digestibility and is currently commercially available. Devlin et al. [32] conducted a study on acid pre-treatments using various $\mathrm{HCl}$ dosage to vary the $\mathrm{pH}$ of various types of sludge from 6 to 1 which led to a reduction of approximately 8 digestion days and an increase in methane yield in comparison to untreated sludge. Similarly, the use of alkali pre-treatment by $[19,32]$ revealed that increasing $\mathrm{pH}$ up to $10-12$ using $\mathrm{KOH}$ and $\mathrm{NaOH}$ can increase the soluble organic fragments by $21.4-93 \%$ and $54-88 \%$ increase in methane generated. The use of ozone has also been adopted to enhance digestion rate and methane generation increased considerably by $>100 \%$. Recently, the use of mechanical pre- and inter-stage treatment via sonication using batch reactors at 100-400 $\mathrm{W}$ for 5-60 min has been demonstrated with improvements in organic compounds solubility, up to 77\% increase in biogas and $42-95 \%$ increase in methane yield [33-35]. Similarly, the use of microwave irradiation of $800-1250 \mathrm{~W}$ at $2.45 \mathrm{GHz}$ for $1-6 \mathrm{~min}$ as pre-treatment increases the biodegradability of sludge by $47-50 \%$, soluble organic fractions by $>117 \%$ and biogas yield by $20-207 \%$. Thermal pre-treatments of $60-180^{\circ} \mathrm{C}$ led to reduction in sludge retention time from 28 days to $12-14$ days and 6.3-16.5\% increase in biogas produced while thermal hydrolysis at a temperature of $130-170{ }^{\circ} \mathrm{C}$ and a pressure of 3.4-7.9 bar reduces the volatile content of the digested sludge by $12.6-62 \%$ and increases biogas yield by 29-59\%. Valo et al. [19] compared the effectiveness of chemical and thermo-chemical pre-treatment for the same sludge using $\mathrm{KOH}$ for increasing alkalinity and thermal treatment at $30-170{ }^{\circ} \mathrm{C}$ for $30-60 \mathrm{~min}$. They discovered an increase in soluble organic content with increase in $\mathrm{pH}$ and temperature with $83 \%$ soluble organic fraction and $36 \%$ increase in organic fraction conversion at $170{ }^{\circ} \mathrm{C}$ with a $\mathrm{pH}$ of 12 . Similar use of thermo-chemical post-treatment using $\mathrm{HCl}$ at $25-180{ }^{\circ} \mathrm{C}$ resulted in almost threefold increase in solubility of organic contents, $6.7-26 \%$ increase in soluble volatile solid conversion and methane production increased by almost $21 \%$. The comparison of the effectiveness of anaerobic digestion with thermo-chemical pre-treatments with inter-stage treatment was done by Nielsen et al [18] using thermal treatments of $80-170{ }^{\circ} \mathrm{C}$ and $\mathrm{KOH}$. The thermal pre-treatments at $80^{\circ} \mathrm{C}$ increased volatile solid by $2-27 \%$ after each treatment stage and $44-57 \%$ increase at $170{ }^{\circ} \mathrm{C}$ and $68-74 \%$ increase when thermo-chemical pre-treatment of $\mathrm{KOH}$ at $170{ }^{\circ} \mathrm{C}$ is utilised. Their observations confirmed the effectiveness of inter-stage treatments in comparison to pre-treatments with increase in methane productions as high as $45 \%$ for thermal inter-stage treatment and $28 \%$ for thermo-chemical inter-treatment in comparison to $2-20 \%$ increase in methane for conventional pre-treatments [18]. Interestingly, the results from these studies reveals the effect of different pre-treatment methods on different sludge types and operating parameters utilized as indicated in Table 1. While some studies have contrasting views on the improvement in the solubility of the organic contents and revealed negligible change in methane yield even with increase in biogas produced, most studies show promising improvements as extensively reviewed by [36]. The use of these pre-treatments and/or inter-stage treatment of the sludge has seen considerable interest in recent years and various commercial applications due to the increase in efficiency of the biogas production, its effectiveness in promoting organic matter decomposition, and reducing organic contents of digestate. 
Table 1. Summary of key research on anaerobic digestion and pre-treatment methods.

\begin{tabular}{|c|c|c|c|c|}
\hline Author(s) & Fuel Types Investigated & Reactor Type Used & Treatment Methods & Observations \\
\hline Devlin et al. [32] & $\begin{array}{l}\text { Thickened waste activated } \\
\text { sludge and inoculum sludge } \\
\text { (15-20 days old) }\end{array}$ & $\begin{array}{l}\text { Full scale, semi-continuous }(12 \\
\text { days) anaerobic digester at } 15 \\
\text { days hydraulic retention time } \\
\text { (HRT) at } 35^{\circ} \mathrm{C}\end{array}$ & $\begin{array}{l}\text { Acid pre-treatment- } \mathrm{HCl} \text { for } \\
\text { attaining } \mathrm{pH} \text { 6-1 (chemical) }\end{array}$ & $\begin{array}{l}\text { Optimal acid dosing for attaining } \mathrm{pH} \text { of } 2 \\
\text { obtained same biogas yield in } 13 \text { digestion } \\
\text { days versus } 21 \text { days required for untreated } \\
\text { sludge. } 14.3 \% \text { increase in methane yield. }\end{array}$ \\
\hline Lin et al. [37] & Pulp and Paper sludge & $\begin{array}{l}\text { Batch reactor at } 42 \text { days } \mathrm{HRT} \text { at } \\
\qquad 37^{\circ} \mathrm{C}\end{array}$ & $\begin{array}{l}\text { Alkali pre-treatment- } 4 \mathrm{~g} / 8 \\
\mathrm{~g} / 16 \mathrm{~g} \mathrm{NaOH} / 100 \mathrm{~g} \text { total solid } \\
\text { sludge (chemical) }\end{array}$ & $\begin{array}{l}54-88 \% \text { increase in methane production with } 8 \\
\mathrm{~g} \mathrm{NaOH} \text { being the optimal amount of } \\
\text { pre-treatment chemical. Alkaline pre-treatment } \\
\text { can be more suitable for soluble chemical } \\
\text { oxygen demands (COD) degradation }(83-93 \%)\end{array}$ \\
\hline Weemaes et al. [38] & Sewage Sludge (7 days old) & $\begin{array}{l}\text { Batch reactor at } 30 \text { days HRT at } \\
\qquad 33^{\circ} \mathrm{C}\end{array}$ & $\begin{array}{l}\text { Ozonation at } 10-50 \mathrm{mg} \mathrm{O} \mathrm{m}_{3} / \mathrm{lgas} \\
\text { for up to } 3 \mathrm{~h} 38 \mathrm{~min} \text { to get } 0.05 \\
\mathrm{~g} / 0.1 \mathrm{~g} / 0.2 \mathrm{~g} \mathrm{O}_{3} / \mathrm{g} \text { COD }\end{array}$ & $\begin{array}{c}\text { Partial oxidation was promoted by the } \\
\text { ozonation reaction which increased methane } \\
\text { production by a factor of } 1.8 \text {. Digestion rate } \\
\text { accelerated by a factor of } 2.2 \text {. Optimal ozone } \\
\text { dose of } 0.1 \mathrm{~g} \mathrm{O}_{3} / \mathrm{g} \text { COD. }\end{array}$ \\
\hline Valo et al. [19] & Waste activated sludge & $\begin{array}{c}\text { Continuous reactor at } 20 \text { days } \\
\text { HRT at } 35^{\circ} \mathrm{C}\end{array}$ & $\begin{array}{l}\text { Alkali pre-treatment: } \mathrm{pH} 10-12 \\
(\mathrm{KOH})\end{array}$ & $\begin{array}{l}21.4 \% \text { increase in soluble COD with increase in } \\
\text { pH from } 10 \text { to } 12\end{array}$ \\
\hline Valo et al. [19] & Waste activated sludge & $\begin{array}{c}\text { Continuous reactor at } 20 \text { days } \\
\text { HRT at } 35^{\circ} \mathrm{C}\end{array}$ & $\begin{array}{l}\text { Thermo-chemical } \\
\text { pre-treatment- } 130^{\circ} \mathrm{C} \text { and } 170 \\
{ }^{\circ} \mathrm{C} \text { for } 30-60 \mathrm{~min}, \mathrm{pH} 10-12 \\
(\mathrm{KOH})\end{array}$ & $\begin{array}{l}21.3 \% \text { increase in soluble COD at } 130^{\circ} \mathrm{C}, \\
\text { further } 32 \% \text { increase in SCOD at } 170{ }^{\circ} \mathrm{C} \text { at } \mathrm{pH} \\
\text { 10. SCOD reaches } 83 \% \text { for } \mathrm{pH} 12 \text { sludge at } 170 \\
{ }^{\circ} \mathrm{C} .72-78 \% \text { increase in biogas yield, } 36.4 \% \\
\text { increase in COD removal was achieved. }\end{array}$ \\
\hline $\begin{array}{l}\text { Takashima and } \\
\text { Tanaka [39] }\end{array}$ & Anaerobically digested sludge & $\begin{array}{l}\text { Batch reactor at } 20 \text { days HRT at } \\
\qquad 35^{\circ} \mathrm{C}\end{array}$ & $\begin{array}{l}\text { Thermo-chemical } \\
\text { post-treatment- } 25^{\circ} \mathrm{C} 100^{\circ} \mathrm{C} \\
\text { and } 180^{\circ} \mathrm{C} \text { for } 1 \mathrm{~h}, \mathrm{pH} 2 / 4 / 6 \\
(\mathrm{HCl})\end{array}$ & $\begin{array}{c}\text { Methane production increased from } 0.11 \mathrm{~g} \\
\text { COD-CH } \mathrm{C}_{4} \text { to } 0.18,0.25 \text { and } 0.32 \mathrm{~g} \text { COD-CH} \\
\text { at } \\
25,100 \text { and } 180^{\circ} \mathrm{C} \text {. Volatile soluble solid } \\
\text { destruction also increased by } 6.7,11.3 \text { and } 26 \% \\
\text { respectively. }\end{array}$ \\
\hline $\begin{array}{l}\text { Takashima and } \\
\text { Tanaka [39] }\end{array}$ & Anaerobically digested sludge & $\begin{array}{c}\text { Continuous reactor at } 20 \text { days } \\
\text { HRT at } 35^{\circ} \mathrm{C}\end{array}$ & $\begin{array}{l}\text { Thermo-chemical } \\
\text { post-treatment- } 170^{\circ} \mathrm{C} \text { for } 1 \mathrm{~h} \text {, } \\
\text { pH } 5-6\left(\mathrm{HCl} \text { and } \mathrm{H}_{2} \mathrm{SO}_{4}\right)\end{array}$ & $\begin{array}{l}\text { Methane production increased by } 14-21 \% \text {. } \\
\text { Volatile soluble solid destruction also increased } \\
\text { by a factor of } 2-2.5 \text {. Optimal dose of } 3.3 \mathrm{mmol} \\
\mathrm{HCl} \text { or } 1.8 \mathrm{mmol}_{2} \mathrm{SO}_{4} \text { per day. }\end{array}$ \\
\hline Nielsen et al. [18] & $\begin{array}{l}\text { Waste activated sludge and } \\
\text { inoculum sludge }\end{array}$ & $\begin{array}{l}\text { Batch reactor for } 40 \text { days or } \\
\text { two-steps of } 19-21 \text { days each in } \\
\text { inter-stage at } 37^{\circ} \mathrm{C}\end{array}$ & $\begin{array}{l}\text { Thermal pre- and inter-stage } \\
\text { treatment at moderate } \\
\text { temperature: water bath at } \\
80^{\circ} \mathrm{C}\end{array}$ & $\begin{array}{l}\text { Pre-treatment: total volatile solid increased } \\
\text { from } 2 \text { to } 29 \% \text {. Inter-stage: total volatile solid } \\
\text { increased from } 2 \text { to } 27 \% \text {. }\end{array}$ \\
\hline
\end{tabular}


Table 1. Cont.

\begin{tabular}{|c|c|c|c|c|}
\hline Author(s) & Fuel Types Investigated & Reactor Type Used & Treatment Methods & Observations \\
\hline Nielsen et al. [18] & $\begin{array}{l}\text { Waste activated sludge and } \\
\text { inoculum sludge }\end{array}$ & $\begin{array}{l}\text { Batch reactor for } 40 \text { days or } \\
\text { two-steps of } 19-21 \text { days each in } \\
\text { inter-stage at } 37^{\circ} \mathrm{C}\end{array}$ & $\begin{array}{l}\text { Thermal pre- and inter-stage } \\
\text { treatment at high temperature } \\
\text { at } 130-170{ }^{\circ} \mathrm{C}\end{array}$ & $\begin{array}{l}\text { Pre-treatment: total volatile solid increased } \\
\text { from } 2 \text { to } 17 \% \text { at } 130{ }^{\circ} \mathrm{C} \text { and } 44 \% \text { at } 170{ }^{\circ} \mathrm{C} \text {. } \\
\text { Methane yield increased by } 13 \% \text { and } 9 \% \\
\text { respectively. Inter-stage: total volatile solid } \\
\text { increased from } 2 \text { to } 25 \% \text { and } 57 \% \text { at } 1300^{\circ} \mathrm{C} \text { and } \\
170^{\circ} \mathrm{C} \text { respectively with } 9 \text { and } 29 \% \text { increase in } \\
\text { methane yield. }\end{array}$ \\
\hline Nielsen et al. [18] & $\begin{array}{l}\text { Waste activated sludge and } \\
\text { inoculum sludge }\end{array}$ & $\begin{array}{l}\text { Batch reactor for } 40 \text { days or } \\
\text { two-steps of } 19-21 \text { days each in } \\
\text { inter-stage at } 37^{\circ} \mathrm{C}\end{array}$ & $\begin{array}{l}\text { Thermochemical pre- and } \\
\text { inter-stage treatment at } 170{ }^{\circ} \mathrm{C} \text {, } \\
\text { pH } 10 \text { using } \mathrm{KOH}\end{array}$ & $\begin{array}{l}\text { Pre-treatment: total volatile solid increased } \\
\text { from } 2 \text { to } 68 \% \text { at } 170{ }^{\circ} \mathrm{C} \text {. Methane yield } \\
\text { increased by } 2 \% \text {. Inter-stage: total volatile } \\
\text { solid increased from } 2 \text { to } 74 \% \text { and } 28 \% \text { increase } \\
\text { in methane yield. }\end{array}$ \\
\hline Riau et al. [33] & $\begin{array}{l}\text { Waste activated sludge and } \\
\text { inoculum sludge }\end{array}$ & $\begin{array}{l}\text { Two batch reactors for } 20 \text { days } \\
\text { solid retention time (SRT) at } 55 \\
{ }^{\circ} \mathrm{C} \text { (thermophilic) and } 35^{\circ} \mathrm{C} \\
\text { (mesophilic) }\end{array}$ & $\begin{array}{l}\text { Mechanical pre- and inter-stage } \\
\text { treatment using sonication at } 24 \\
\mathrm{KHz}, 400 \mathrm{~W} \text { at } 5-10 \mathrm{~min}\end{array}$ & $\begin{array}{l}\text { Total methane production increased by } 42 \% \text {, } \\
\text { volatile solid removal by } 13 \% \text { and SCOD } \\
\text { elimination was increased by } 22 \% .\end{array}$ \\
\hline Martín et al. [34] & Sewage Sludge & $\begin{array}{c}\text { Batch reactor at } 35^{\circ} \mathrm{C} \text { for } \\
10 \text { days }\end{array}$ & $\begin{array}{l}\text { Mechanical pre-treatment using } \\
\text { sonication at } 150 \mathrm{~W} \text { at } 0-60 \mathrm{~min}\end{array}$ & $\begin{array}{l}38-91 \% \text { soluble COD fraction. } 64-95 \% \text { increase } \\
\text { in methane yield with optimal enhancement at } \\
45 \mathrm{~min} \text { sonication. }\end{array}$ \\
\hline Houtmeyers et al. [35] & Thickened sludge (500 g) & $\begin{array}{l}\text { Semi-continuous reactor at } 20 \\
\text { days HRT for } 67 \text { days at } 37^{\circ} \mathrm{C}\end{array}$ & $\begin{array}{c}\text { Mechanical pre-treatment using } \\
\text { ultrasonic pre-treatment at } 100 \\
\text { W at } 8 \mathrm{~min}\end{array}$ & $\begin{array}{c}1741 \% \text { increase in soluble COD fraction. } 24 \% \\
\text { increase in Sludge removal. } 27 \% \text { increase in } \\
\text { biogas yield }\end{array}$ \\
\hline Houtmeyers et al. [35] & Thickened sludge (500 g) & $\begin{array}{l}\text { Semi-continuous reactor at } 20 \\
\text { days HRT for } 67 \text { days at } 37^{\circ} \mathrm{C}\end{array}$ & $\begin{array}{l}\text { Physiochemical pre-treatment } \\
\text { using microwave radiation at } \\
800 \mathrm{~W} \text { at } 2.45 \text { ghz for } 1 \mathrm{~min}\end{array}$ & $\begin{array}{c}117 \% \text { increase in soluble COD fraction. } 45 \% \\
\text { increase in Sludge removal. } 20 \% \text { increase in } \\
\text { biogas yield }\end{array}$ \\
\hline Ebenezer et al. [40] & Activated Sludge & $\begin{array}{l}\text { Batch reactor at } 35^{\circ} \mathrm{C} \text { for } \\
35 \text { days }\end{array}$ & $\begin{array}{l}\text { Physiochemical pre-treatment } \\
\text { using microwave radiation at } \\
900 \mathrm{~W} \text { at } 2.45 \text { ghz for } 30-300 \mathrm{~s} \\
\left(40-96^{\circ} \mathrm{C}\right)\end{array}$ & $\begin{array}{c}950 \% \text { increase in soluble COD fraction. } 47 \% \\
\text { increase in biodegradability. Increase in } \\
\text { biogas yield. }\end{array}$ \\
\hline Coelho et al. [41] & Thickened sludge & $\begin{array}{l}10 \text { semi-continuous reactors for } \\
20 \text { days at } 55^{\circ} \mathrm{C} \text { (thermophilic) } \\
\text { and } 35^{\circ} \mathrm{C} \text { (mesophilic) }\end{array}$ & $\begin{array}{l}\text { Physiochemical pre-treatment } \\
\text { using microwave radiation at } \\
1250 \mathrm{~W} \text { at } 2.45 \text { ghz for } 6 \mathrm{~min}\end{array}$ & $\begin{array}{l}63-207 \% \text { increase in biogas production. } 50 \% \\
\text { increase in volatile solid removal. }\end{array}$ \\
\hline
\end{tabular}


Table 1. Cont.

\begin{tabular}{|c|c|c|c|c|}
\hline Author(s) & Fuel Types Investigated & Reactor Type Used & Treatment Methods & Observations \\
\hline Appels et al. [42] & Activated Sludge & $\begin{array}{l}\text { Semi-continuous reactor at } 20 \\
\text { days HRT-42 days at } 37^{\circ} \mathrm{C}\end{array}$ & $\begin{array}{l}\text { Physiochemical pre-treatment } \\
\text { using microwave radiation at } \\
800 \mathrm{~W} \text { at } 2.45 \text { ghz for } 3.5 \mathrm{~min}\end{array}$ & $\begin{array}{l}214 \% \text { increase in soluble COD fraction. } 50 \% \\
\text { Increase in biogas yield. } 67 \% \text { increase in } \\
\text { solids removal. }\end{array}$ \\
\hline Wilson et al. [43] & Mixed sludge & $\begin{array}{l}\text { Semi-continuous reactor at } \\
15-20 \text { days SRT at } 37-42{ }^{\circ} \mathrm{C}\end{array}$ & $\begin{array}{l}\text { Thermal hydrolysis } \\
\text { pre-treatment at } 150-170{ }^{\circ} \mathrm{C} \text {, } \\
4.8-7.9 \text { bar. }\end{array}$ & $\begin{array}{l}56-62 \% \text { reduction in volatile solid in digestate. } \\
24-59 \% \text { increase in biogas production }\end{array}$ \\
\hline Pilli et al. [44] & $\begin{array}{l}\text { Primary, Secondary and } \\
\text { mixed sludge }\end{array}$ & $\begin{array}{l}\text { Semi-continuous reactor at } 30 \\
\text { days SRT at } 35^{\circ} \mathrm{C}\end{array}$ & $\begin{array}{l}\text { Thermal pre-treatment using } \\
\text { hydrolyser at } 134-140^{\circ} \mathrm{C}, 3.4 \\
\text { bar for } 30 \mathrm{~min} .\end{array}$ & $\begin{array}{l}12.6 \% \text { reduction in volatile solid in digestate. } \\
40.2 \% \text { increase in methane production }\end{array}$ \\
\hline Xue et al. [45] & $\begin{array}{l}\text { dewatered sludge (high } \\
\text { solid sludge) }\end{array}$ & $\begin{array}{l}\text { Batch reactor at } 28 \text { days SRT at } \\
\qquad 37^{\circ} \mathrm{C}\end{array}$ & $\begin{array}{l}\text { Thermal pre-treatment using } \\
\text { low temperature hydrolysis at } \\
60-90^{\circ} \mathrm{C} \text {, for } 1-72 \mathrm{~h}\end{array}$ & $\begin{array}{c}557-1678 \% \text { increase in SCOD, negligible } \\
\text { change in biogas yield. Optimal SRT of } \\
18-20 \text { days }\end{array}$ \\
\hline Xue et al. [45] & $\begin{array}{l}\text { dewatered sludge (high } \\
\text { solid sludge) }\end{array}$ & $\begin{array}{l}\text { batch reactor at } 28 \text { days SRT at } \\
\qquad 37^{\circ} \mathrm{C}\end{array}$ & $\begin{array}{l}\text { Thermal pre-treatment using } \\
\text { high temperature hydrolysis at } \\
120-180^{\circ} \mathrm{C} \text {, for } 15-180 \mathrm{~min}\end{array}$ & $\begin{array}{l}582-1087 \% \text { increase in SCOD, } 6.3-16.5 \% \\
\text { increase in biogas yield. SRT reduction to } \\
12-14 \text { days }\end{array}$ \\
\hline
\end{tabular}


However, these improvements come at additional energy, chemical reagents and operational costs as listed out in the advantages and disadvantages given in Table 2. Although increase in methane yield is prominent with most of these pre-treatment methods, high energy requirements remains a major hindrance for thermal, microwave and mechanical treatments with high capital cost as an additional disadvantage for thermal and microwave technologies. The benefits of simplicity and low technology cost can be found in mechanical and chemical pre-treatments, however the potential for toxicity and high cost of chemicals remains a challenge for chemical pre-treatments. Other pre-treatment methods are biological techniques such as microbial electrolysis cell and enzymatic hydrolysis are still undergoing lab-scale experiments. 
Table 2. Advantages and disadvantages of various sludge pre-treatment methods.

\begin{tabular}{|c|c|c|c|c|c|}
\hline & $\begin{array}{c}\text { Chemical (Acid or Alkali } \\
\text { Treatment) }\end{array}$ & Chemical (Ozonation) & Ultrasonication & Microwave Irradiation & Thermal Treatment \\
\hline \multirow{3}{*}{ Pro(s) } & Methane yield increase & Methane yield increase & Methane yield increase & Methane yield incre & methane yield incr \\
\hline & Simple and easy to integrate & Flexible operation & Low cost pre-treatment method & Fast and uniform heating process & Reduce sludge volume \\
\hline & Low cost pre-treatment method & Reduced sludge volume & Easy maintenance & Easy to control & Improves dewater-ability \\
\hline \multirow{3}{*}{ Con(s) } & High cost of chemicals & High energy requirements & High energy requirements & High energy requirements & High energy requirements \\
\hline & Special reactor requirements & $\begin{array}{l}\text { Mineralization potential } \\
\text { of cellular matter }\end{array}$ & $\begin{array}{l}\text { Unsuitable for lignocellulosic } \\
\text { biomass }\end{array}$ & Scale up challenges & High capital cost \\
\hline & Toxicity of some alkali like $\mathrm{Na}+$ & - & - & - & Potential for ammonia generation \\
\hline
\end{tabular}


The combination of different energy technologies such as anaerobic digestion followed with pyrolysis has been presented by Cao and Pawlowski [46] for maximisation of energy efficiency in comparison to the use of the technologies independently. The use of anaerobic digestion is particularly attractive as it fulfils most of the requirements in European Waste reuse and recovery hierarchy and its use in combination with food waste has been proposed by Morales-Polo et al. [47] due to the added benefit of nutrient enrichment, increase in alkalinity, reduced ammonia and enhanced stability of the process. Furthermore, $\sim 20-40 \%$ increase in production of bio-methane was obtained from the co-digesting of mixed sludge and organic food waste by boosting the decomposition of acetate during methanogenesis [48]. Similar observations were reported by Guimarães et al. [49] where increase in volatile solid reduction, methane production was observed on co-digestion of sludge and food waste. However, such mix of waste feedstocks would also impose higher need for process control. In depth evaluation on anaerobic digestion has been done by Meegoda et al [21] and the cost of pre-treatment versus the modest increase in biogas requires crucial justification ensure cost effectiveness.

In summary, even with the systematic comparison of various pre-treatments routes on anaerobic digestion, the technology with all its benefits still remains hindered with high cost and low conversion efficiency. These limitations are depicted in Figure 4. As technological feasibility is dependent on sludge degradation and methane conversion efficiency, most of these researches fail to consider the energy, life cycle, environmental and economic costs of these pre-treatment methods which must be taken into account for a sustainable process. Apart from the optimization of process parameter for improving biodegradability of digestate, critical life cycle assessment is required for these treatment strategies for determining practicality. This is because the additional cost, energy and/or chemical inputs required by these pre-treatment techniques to maximize biogas yield may not necessarily be energy, environment or cost efficient and its impacts must be analysed before such can be implemented in practice. 


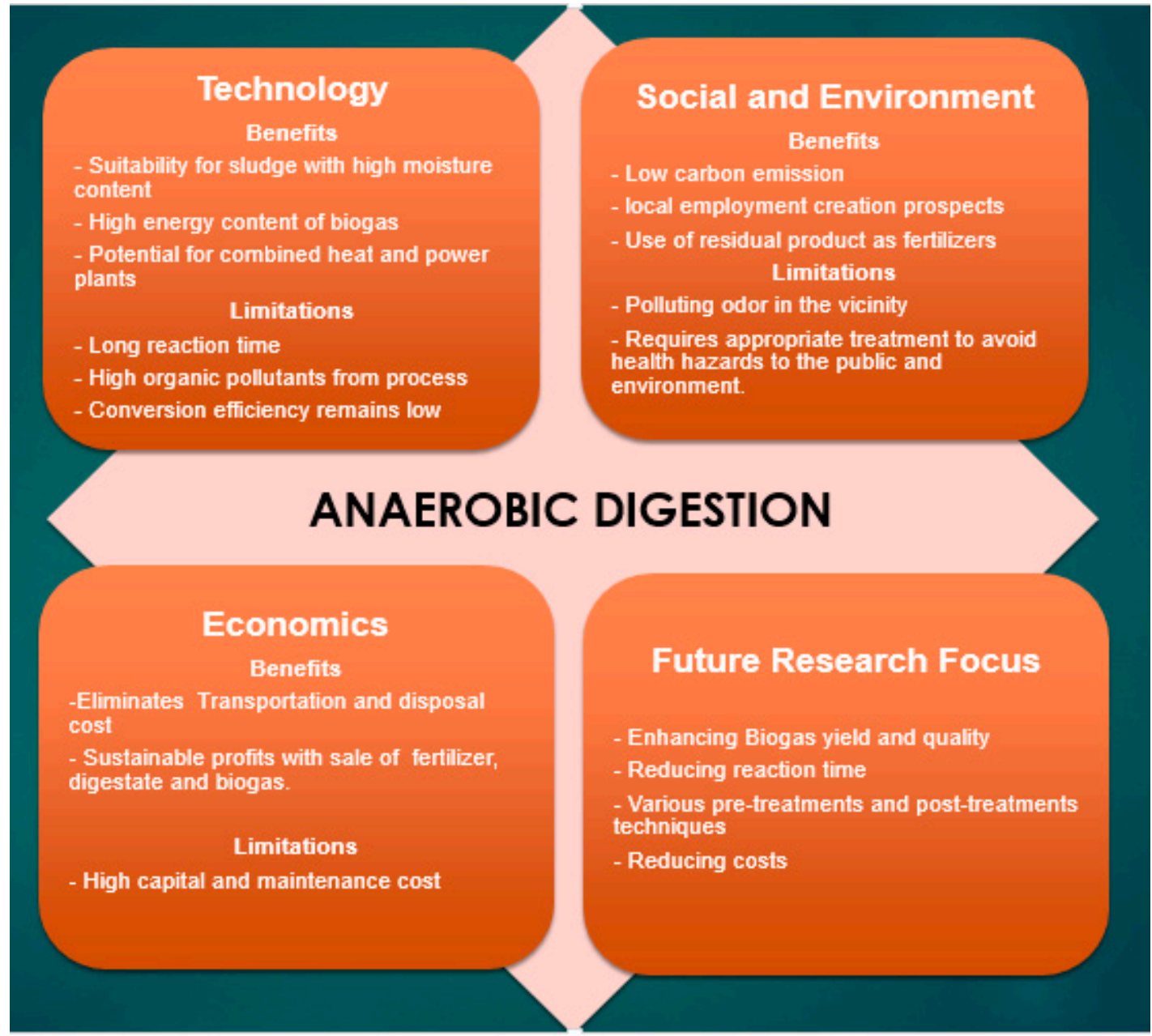

Figure 4. Technological, Socio-environmental and Economic Assessment of Anaerobic Digestion for Sludge Processing.

\subsection{Combustion}

The combustion of all solid fuels is similar to that of sewage sludge. It involves the high temperature oxidation of fuels to obtain heat, carbon dioxide, water vapour and other trace gases. However, the use of combustion technology for waste materials such as sludge can be used for primarily generating heat (conventional combustion) or for reducing the volume of the waste materials (incineration). The conventional use of the heat generated from combustion technology is for heating or electric power generation via heat engines whereas incineration systems may or may not utilise the heat generated from combustion as their main purpose is for burning off harmful elements from waste before final disposal or re-use of residual ash in the construction industry. This is because incineration has been observed to reduce up to $90 \%$ of the sludge volume while terminating pathogens [50]. This use of incinerators is famous for clinical and municipal solid wastes and it has gained more attention recently due to the need of reducing the use of cultivable land for waste disposal [2]. The principle of solid fuel combustion involves drying, pyrolysis, volatiles combustion, char combustion, ash melting and agglomeration. These stages occur sequentially or simultaneously depending on the configuration, reactor conditions and fuel properties. For instance, some sludge and biomass could start pyrolysis at low temperature $\left(\sim 150^{\circ} \mathrm{C}\right)$ typical for the fuel drying [51,52]. The release and burning of volatiles from this stage generates heat, $\mathrm{CO}, \mathrm{H}_{2} \mathrm{O}, \mathrm{CO}_{2}, \mathrm{NOx}$ and $\mathrm{SOx}$ which further interacts with the solid char particles in the fuel and increase surface temperatures. This mostly occurs earlier than the oxidising agent of the reactor reaches the required temperature or diffuses sufficiently to initiate char oxidation. This process is common during combustion of wet sludge, particularly waste of 
bulky particle sizes and is referred to as auto-gasification due to the high steam generated during the burning [53]. The representative chemical reactions are detailed in Equations (1)-(10) below.

Pyrolysis (inert atmosphere- $\mathrm{N}_{2} ; 350-700^{\circ} \mathrm{C}$ ):

$$
\mathrm{C}_{\mathrm{n}} \mathrm{H}_{\mathrm{m}} \mathrm{O}_{\mathrm{p}} \rightarrow \mathrm{CO}_{2}+\mathrm{H}_{2} \mathrm{O}+\mathrm{CH}_{4}+\mathrm{CO}+\mathrm{H}_{2}+\left(\mathrm{C}_{2}-\mathrm{C}_{5}\right)
$$

Partial oxidation (oxygen lean atmosphere):

$$
\begin{gathered}
\mathrm{C}+\mathrm{O}_{2} \rightarrow \mathrm{CO}_{2} \\
\mathrm{C}+\frac{1}{2} \mathrm{O}_{2} \rightarrow \mathrm{CO} \\
\mathrm{H}_{2}+\frac{1}{2} \mathrm{O}_{2} \rightarrow \mathrm{H}_{2} \mathrm{O}
\end{gathered}
$$

Gasification (oxygen lean atmosphere- $\mathrm{CO}_{2}, \mathrm{H}_{2} \mathrm{O} ; 800-1100{ }^{\circ} \mathrm{C} ; 1-33$ bar):

$$
\begin{gathered}
\mathrm{C}+\mathrm{H}_{2} \mathrm{O} \rightarrow \mathrm{CO}+\mathrm{H}_{2} \\
\mathrm{C}+2 \mathrm{H}_{2} \mathrm{O} \rightarrow \mathrm{CO}_{2}+2 \mathrm{H}_{2} \\
\mathrm{C}+\mathrm{CO}_{2} \rightarrow 2 \mathrm{CO}
\end{gathered}
$$

Methanation (further reaction):

$$
\begin{aligned}
& \mathrm{CO}+3 \mathrm{H}_{2} \rightarrow \mathrm{CH}_{4}+\mathrm{H}_{2} \mathrm{O} \\
& \mathrm{C}+\mathrm{H}_{2} \mathrm{O} \rightarrow \frac{1}{2} \mathrm{CH}_{4}+\frac{1}{2} \mathrm{CO}_{2}
\end{aligned}
$$

Combustion (oxygen rich environment-air or $\mathrm{O}_{2}$ ):

$$
\mathrm{CH}_{4}+2 \mathrm{O}_{2} \rightarrow 2 \mathrm{H}_{2} \mathrm{O}+\mathrm{CO}_{2}
$$

The volatiles combustion dominates the heat production from sludge combustion as the char contribution is relatively negligible. The increase of the surface temperature of the fuel from volatile combustion leads to the melting of some ash matter which may results in ash melts covering the particle surface at temperatures $\geq 900{ }^{\circ} \mathrm{C}$. The char combustion proceeds with increasing temperature and increases the proportion of gaseous compounds till burn out which occurs quickly (equivalent or lower time span as the devolatilization stage) due to the low fixed carbon content of sludge $[54,55]$. This has also been attributed to the high char reactivity induced by the inorganic constituents char. Finally, the agglomeration of the ash particles is facilitated by the heat from char combustion and after the maximum surface temperature is reached; cooling begins gradually which indicates combustion completion [56]. This suggests that the burning off of all the organics and the melting and agglomeration of ash is required for the decrease in sludge volume during incineration while the drying, devolatilization and burning of volatiles is more crucial for the conventional combustion system for heat generation [16]. This indicates the considerations required for combustion and incineration efficiency. Such systems need to be equipped with flue gas cleaning facilities to minimise emissions, fly ash or hazardous gas emissions.

Unlike the anaerobic digestion where the dewatered sludge can be used directly, combustion requires further drying of the dewatered sludge to reduce the moisture content to $<50 \mathrm{wt} \%$ before being fed into the reactor as seen in Figure 5. 


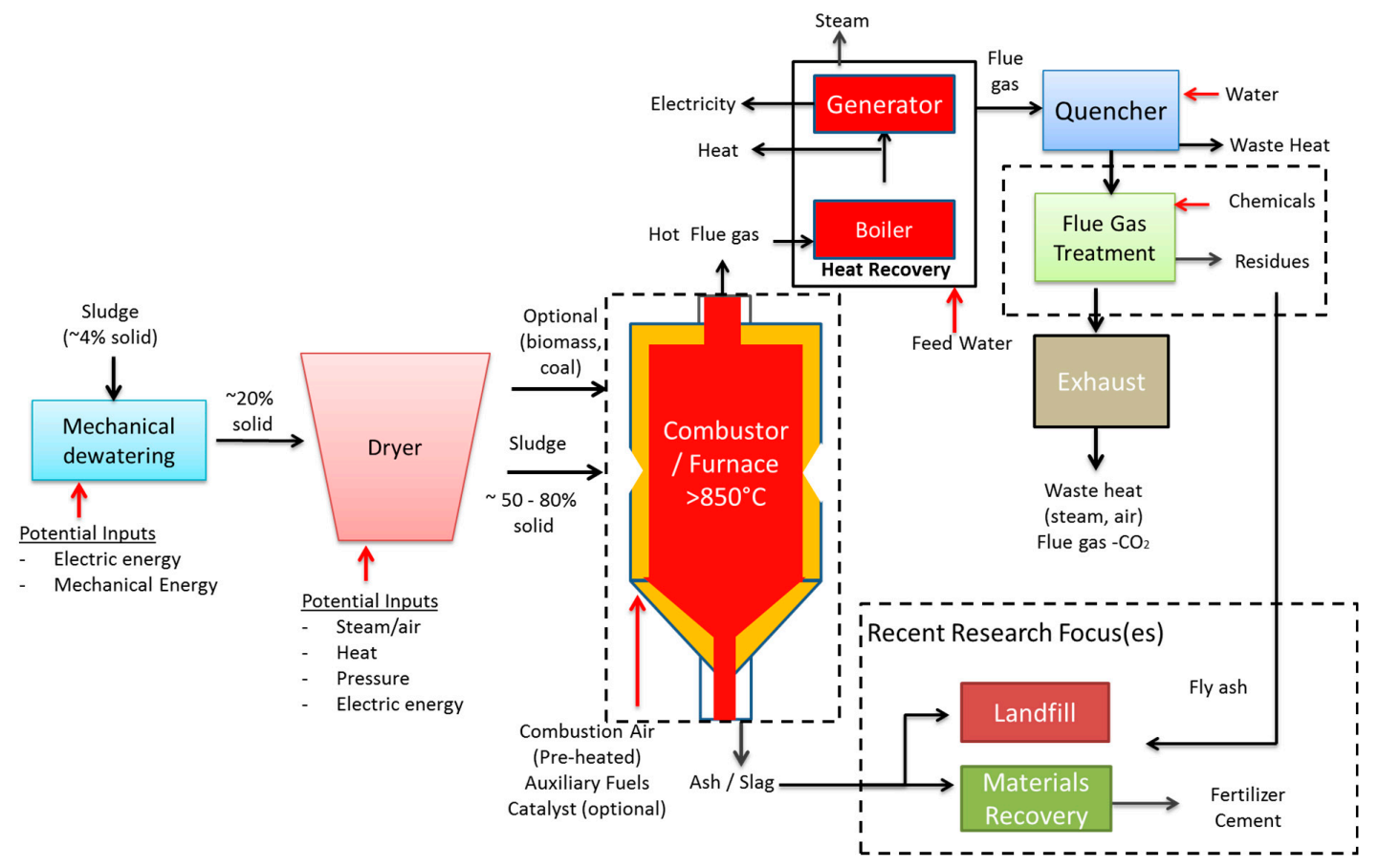

Figure 5. Schematic Representation of the Combustion of sludge.

The energy requirements of this drying process is quite endothermic. The drying requirements and acceptable moisture content is dependent on the furnace type as this would greatly influence the efficiency of the reactor. This is particularly important because of the heat loss from evaporation of sludge's moisture content. In addition, high moisture is one of the precursors of incomplete combustion. The furnace operates at temperatures $>850{ }^{\circ} \mathrm{C}$ for the complete oxidation of sludge which is done individually or blended with other solid fuels (coal or biomass) $[57,58]$. This process would require excess air for completion while auxiliary fuels and catalysts might be needed for initiation and maintaining reaction stability for operational efficiency. Ash and Flue gas are the main output from this reactor. The flue gas is made up primarily of oxides of carbon, nitrogen, sulphur and particulate matter which acts as the thermal store that allows heat transfer from itself to feed water. This aids in heat generation for direct use (industrial or residential heating) or electricity generation via steam turbines and generators. After the heat recovery process, the flue gas has to undergo treatment for eliminating pollutants before releasing exhaust gases (mostly $\mathrm{CO}_{2}$ and water vapour) into the atmosphere. The ash generated from this process can be either disposed of at the landfill or reused in agricultural or construction applications. However, this is primarily dependent on its chemical contents, particularly, the heavy metal contents of the ash.

Various combustion reactors are used such as multiple hearth, rotary kiln, and cyclone and fluidised bed furnace which have different fuel feeding mode, operating mode, advantages and disadvantages. However, fluidised bed furnace is quite popular for wet ( $35-59 \%$ moisture) and dried sludge due to its simplicity, inexpensive cost, uniform heating, low pollutants in flue gas $(\leq 50 \%$ $\mathrm{CO}$ and NOx pollution, $\leq 40 \% \mathrm{CO}_{2}$ ), lower residence time and high combustion efficiency [59-61]. Such technologies are also known for reducing cost associated with supplementary fuel such that about $0.2-1$ million dollars savings has been realised annually from operational plants [16]. Recent studies are mainly focussed on three fields: (i) improving combustion reactivity and completion by optimising reaction parameters, utilising catalysts and co-blending with other fuels such as coal, oil shale and biomass [57,58,62-67]; (ii) utilisation of ash and fly ash generated from the process as fertilizer or cement [68-70]; and (iii) pollutants and toxic emission reduction for reducing CO, NOx, SOx and PAH emissions while preventing heavy metal emissions $[58,61,70]$. Recent works on sewage sludge combustions have been summarised in Table 3. The blending of sludge with other 
solid fuels has been observed to increase the reactivity and reduce reaction time of the fuel blends during combustion due to the high volatility of sludge [63-67]. Co-blending with sludge increased the mechanical properties of the ash which supports utilisation in construction industries as cement [70]. In addition to this, the use of catalysts such as $\mathrm{CeO}_{2}$ and $\mathrm{Fe}_{2} \mathrm{O}_{3}$ was studied by Wang et al. [65] which revealed further enhancement in the ignition and combustion properties of the blends. The main challenge with combustion of sewage sludge is mostly the high moisture and ash content which influences the thermal characteristics of the fuel and the design requirements of the combustor. High moisture content is not only deterrent for increasing the bulk density of the fuel, lowering the energy content and causing incomplete oxidation, it also requires additional time, oxidants and energy for drying the sludge and has potential for forming erosive sulphuric compounds [71]. Additionally, sludge with $>80 \%$ moisture content requires auxiliary fuels for sustaining the reaction which results in low heating values [72]. Apart from moisture, the high ash content and the changes that occurs with increase in temperature such as melting, slagging, agglomeration, corrosion and emission of heavy metals are problematic in sewage sludge combustion. It is essential to understand the transformation of these inorganic compounds and their behaviours during combustion due to its importance in the operation and maintenance of the reactors. The slagging and agglomeration concerns in sewage sludge combustion is related to both alkali-induced and silicate melt induced deposition of ash on reactor surfaces. This would lead to reduction in thermal efficiency of the process and raise operational cost. Furthermore, the high chlorine content associated with sludge, mostly from iron chloride used in water treatment plants, poses high corrosion risk in the combustor. The final concern associated with sewage sludge ash is heavy metals emission which has adverse effect on health and environment. Studies on co-combustion of sewage sludge with rice husk done by Rong et al. [57] described reduction in the slagging potential of sludge ash due to co-blending with $\mathrm{SiO}_{2}$ rich rice husk. Their observations also includes synergistic interactions in the combustion properties of the co-blended fuels as long as sewage sludge addition remains $\leq 30 \mathrm{wt} \%$. The high phosphorus content in sewage sludge fly ash enables potential application in agriculture as a fertilizer as established by Niu and Shen [70] but the risk of phosphate formation poses eutrophication threats. Comprehensive explanations of ash related concerns and usage in sewage sludge combustion has been reviewed by others [2,54]. The reduction of up to $15.7 \% \mathrm{CO}$ and $26.5 \% \mathrm{NO}$ has been observed by Hao et al. [72] by controlling the operating temperature from $600-1000{ }^{\circ} \mathrm{C}$ in an horizontal tube furnace. Studies by Chen et al. [58] where shiitake substrate and Australian black coal were blended with sewage sludge attained improvements in ignition and reductions in NOx and SOx emissions. Similar results were published by Batistella et al. [61] who reduced $\mathrm{CO}, \mathrm{PAH}$ and NOx by controlling and optimising dryer temperature, oxygen content, and reaction temperature in a multi-stage combustion unit. However, both of these studies revealed increase in SOx emissions from the flue gas. 
Table 3. Summary of key research on combustion of sewage sludge.

\begin{tabular}{|c|c|c|c|}
\hline Author(s) & Fuel Types Investigated & Reactor Type Used & Observations \\
\hline Hao et al. [72] & $\begin{array}{l}\text { Thermally dried (TD) and bio-dried } \\
\text { (BD) sewage sludge }(50-450 \mu \mathrm{m})\end{array}$ & $\begin{array}{l}\text { Horizontal tube furnace for } \\
\text { isothermal combustion at 600-1000 } \\
\left.{ }^{\circ} \mathrm{C} \text { (air, } 10 \mathrm{~min}\right)\end{array}$ & $\begin{array}{l}\text { Removal of } \sim 26 \% \text { more moisture in BDSS resulted in higher LHV }(37.9 \%) \text {, higher combustion index and } \\
\text { prevents incomplete combustion. } 20 \% \text { and } 15.7 \% \text { less nitrogenous gas and CO emission in the flue gas. } \\
\text { Up to } 26.5 \% \text { less NO but increase in } \mathrm{SO}_{2} \text { emitted in BDSS in comparison to TDSS. }\end{array}$ \\
\hline Niu and Shen [68] & $\begin{array}{l}\text { Dewatered Sewage sludge } \\
\quad(200-450 \mu \mathrm{m})\end{array}$ & $\begin{array}{l}\text { Quartz fluidized bed for chemical } \\
\text { looping combustion at } 850-950^{\circ} \mathrm{C}(5 \\
\text { vol } \% \mathrm{O}_{2} \text { in } \mathrm{N}_{2} \text { and reduced by } 8 \\
\text { vol } \% \mathrm{CO}, 15 \mathrm{~min})\end{array}$ & $\begin{array}{l}\text { High Phosphorus (66.8-69.3\%) availability in fly ash from sewage sludge processing with potential to } \\
\text { use as fertilizer. However, The high P content influences the activity of the hematite oxygen carrier in } \\
\text { the reaction. Ca and Fe in sludge ash promoted the reduction reactivity of the hematite. }\end{array}$ \\
\hline Cheng et al. [69] & $\begin{array}{l}\text { Air dried Municipal sewage sludge } \\
\qquad(80-120 \mu \mathrm{m})\end{array}$ & $\begin{array}{l}\text { Thermogravimetric analyzer (TGA) } \\
\text { at } 800{ }^{\circ} \mathrm{C}, 40{ }^{\circ} \mathrm{C} / \mathrm{min}(100 \mathrm{~mL} / \mathrm{min} \\
\left.\mathrm{N}_{2} \text { with } 0-20 \% \mathrm{O}_{2}\right)\end{array}$ & $\begin{array}{r}\text { Main difference in the reaction in inert atmosphere and slightly o } \\
\text { and ash combustion zone. } \sim 10 \text { vol\% } \mathrm{O}_{2} \text { was adequate for comp } \\
\text { although at higher temperature range in comparis }\end{array}$ \\
\hline Chen et al. [70] & Rice husk and sewage sludge & $\begin{array}{l}\text { Muffle furnace at } 600 \& 750^{\circ} \mathrm{C} \text { for } \\
\text { sewage sludge and rice husk/sewage } \\
\text { sludge ash }\end{array}$ & $\begin{array}{l}\text { High Fe and heavy metals in sewage sludge ash. In the rice husk/sewage sludge blend, heavy metals } \\
\text { were stabilized, reducing emission and retention in ash. Mechanical properties of the ash derived from } \\
\text { co-combustion has potential use as cement material substitute. }\end{array}$ \\
\hline $\begin{array}{l}\text { Kijo-Kleczkowska, } \\
\text { et al. [62] }\end{array}$ & $\begin{array}{l}\text { Sewage sludge; brown and hard coal; } \\
\text { pine and straw (as pellets) }\end{array}$ & Bench reactor at $800-900^{\circ} \mathrm{C}$ in air & $\begin{array}{l}\text { Visually detected reaction time-Coal }(403-700 \mathrm{~s})>\text { Sewage Sludge }(200 \mathrm{~s})>\text { Biomass }(80-100 \mathrm{~s}) \text {. } \\
\text { Volatiles / Char combustion time-Coal }(9-20 ; 77-88 \%) \text {; Sludge }(23 / 73 \%) \text {; biomass }(26-27 ; 68-70 \%) \text { of } \\
\text { reaction time. However, the volatiles oxidation is the most important stage for biomass and sludge } \\
\text { combustion. Optimisation of reactor temperature and air flow velocity for different particle size such } \\
\text { that at } 7.5 \mathrm{~mm} \text {, sludge requires } 800-800^{\circ} \mathrm{C} \text { and } 2.8 \mathrm{~m} / \mathrm{s} \text { to minimise ignition time and surface } \\
\text { temperature of fuel while ensuring burnout. This could be used to match fuels that can be co-blended } \\
\text { together i.e., brown coal or willow with } 800-850^{\circ} \mathrm{C} \text { and } 2.8 \mathrm{~m} / \mathrm{s} \text { optimal condition. }\end{array}$ \\
\hline Batistella et al. [61] & Dewatered sewage sludge & $\begin{array}{l}\text { Pilot scale Rotary dryer }\left(128-354^{\circ} \mathrm{C} \text { ) }\right. \\
\text { with Moving bed combustor at } \\
700-800{ }^{\circ} \mathrm{C} \text { (Inlet); } 950-1150{ }^{\circ} \mathrm{C} \text { (post } \\
\text { combustion) }\end{array}$ & $\begin{array}{l}\text { CO emission was negligible from the combustor, however the dehydration process at lower temperature } \\
\text { emits CO. This was reduced by controlling and optimizing the oxygen content (from exhaust gas) and } \\
\text { temperature of the dryer. } \\
\text { The NOx emissions remained below standard limits by optimising excess air, air/fuel feed rate and } \\
\text { maintaining low reaction temperature. The high temperature in the post combustion chamber aided } \\
\text { decomposition of PAH in flue gas. Low calcium content of fuel resulted in higher SOx emission and } \\
\text { high particulate matter. }\end{array}$ \\
\hline Lin et & $\begin{array}{l}\text { Activated sewage sludge and } \\
\text { dewatered oil shale blends at } 10,30 \\
50,70,90 \mathrm{wt} \% \text { sludge }(<178 \mu \mathrm{m})\end{array}$ & $\begin{array}{r}\text { Thermogravimetri } \\
\text { at } 1000^{\circ} \mathrm{C}, 10 \\
(80 \mathrm{~mL} / 1\end{array}$ & $\begin{array}{l}\text { Blending with sewage sludge resulted in easier ignition properties due to its higher volatile content. } \\
\text { Ash content increased due to higher ash of oil shale. Blends with } 10 \mathrm{wt} \% \text { sludge resulted in combustion } \\
\text { promotion by reducing activation energy. }\end{array}$ \\
\hline Huang et al. [64] & $\begin{array}{c}\text { Sewage sludge and water hyacinth } \\
\text { blends at } 10,20,30 \text { and } 40 \mathrm{wt} \% \text { water } \\
\text { hyacinth }\end{array}$ & $\begin{array}{l}\text { TGA at } 10000^{\circ} \mathrm{C}, 10-40^{\circ} \mathrm{C} / \mathrm{min} \\
\quad\left(50 \mathrm{~mL} / \mathrm{min} \mathrm{CO}_{2} / \mathrm{O}_{2}\right)\end{array}$ & $\begin{array}{r}\text { Drying and combustion reaction zone of sewage sludge was } \\
\text { enhancing reactiv }\end{array}$ \\
\hline Wang et al. [65] & $\begin{array}{l}\text { Sewage sludge and bituminous coal } \\
\text { blends at } 5-50 \mathrm{wt} \%(<75 \mu \mathrm{m}) \text {. }\end{array}$ & $\begin{array}{l}\text { TGA at } 900{ }^{\circ} \mathrm{C}, 20^{\circ} \mathrm{C} / \mathrm{min} \\
\left(80 \mathrm{~mL} / \mathrm{min} \mathrm{N}_{2} / \mathrm{O}_{2}\right) \\
5 \% \text { catalyst }\left(\mathrm{CaO}_{1} \mathrm{CeO}_{2}, \mathrm{MnO}_{2}\right. \\
\left.\text { and } \mathrm{Fe}_{2} \mathrm{O}_{3}\right)\end{array}$ & $\begin{array}{l}\text { The blending of sewage sludge with coal at high fractions }(>10 \mathrm{wt} \%) \text { deteriorated the combustion } \\
\text { characteristics of the blends in comparison to coal. } \\
\text { The use of catalysts, particularly Ce- and Fe-based, drastically improved the ignition and combustion } \\
\text { properties of the blends. }\end{array}$ \\
\hline $\begin{array}{l}\text { Kijo-Kleczkowska } \\
\text { et al. [66] }\end{array}$ & $\begin{array}{l}\text { Sewage sludge blended with lignite, } \\
\text { hard coal and willow at 50:50 wt } \% \\
\text { (as pellets) }\end{array}$ & ench reactor at $800-900{ }^{\circ} \mathrm{C}$ in air & $\begin{array}{c}\text { Volatiles / Char combustion time-Sludge }+ \text { lignite }(24 ; 73 \%) \text {; Sludge }+ \text { hard coal }(13 / 84 \%) \text {; sludge }+ \\
\text { willow }(28 ; 67 \%) \text { of reaction time. Blending with sludge reduces ignition time especially in coal samples, } \\
\text { extends the reaction time for biomass blend and maximum surface temperature. }\end{array}$ \\
\hline Deng et al. [67] & $\begin{array}{l}\text { Sewage sludge and wheat straw } \\
\text { blends at } 20-80 \mathrm{wt} \% \text { biomass } \\
\qquad(<200 \mu \mathrm{m})\end{array}$ & $\begin{array}{l}\text { TGA at } 1000{ }^{\circ} \mathrm{C}, 2 \\
(100 \mathrm{~mL} / \mathrm{min} \mathrm{N}\end{array}$ & $\begin{array}{l}\text { The addition of wheat straw to sewage sludge improves the char combustion reactivity and heat } \\
\text { released due to changes in physiochemical properties such as higher surface area and pore volume of } \\
\text { the pyrolytic char. }\end{array}$ \\
\hline
\end{tabular}


Some of these benefits and limitations are highlighted in Figure 6.

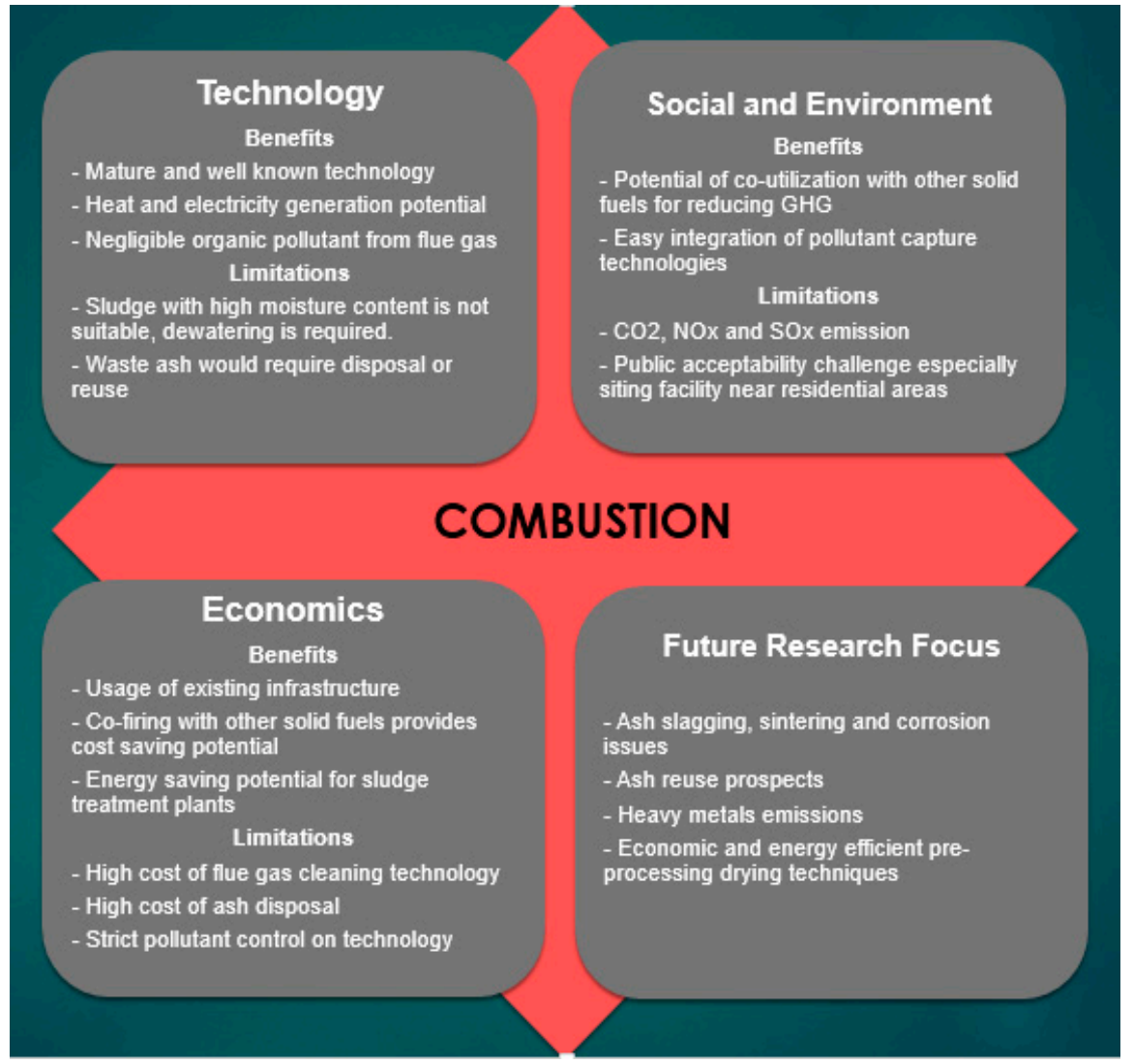

Figure 6. Technological, Socio-environmental and Economic Assessment of Combustion for Sludge Processing.

Several flue gas cleaning and particulate control measures have to be integrated to minimise the release of such metals but some highly volatile elements such as mercury, cadmium and lead may be released as vapour. Furthermore, the use of the subsequent ash or slags for other applications must also be reflected upon, particularly those with high phosphorus contents and negligible toxic compounds such as heavy metals or polycyclic aromatic hydrocarbons (PAHs) that can be used for agricultural reclamation or in construction industry. Co-use of sludge with other fuels such as coal, biomass, other solid waste, fuel oil or gas has been investigated as a means of avoiding the high cost associated with dedicated reactors, an avenue for reducing net carbon emissions from coal power plants, increasing calorific value and/or improving energy efficiency of the system $[62,65,70,73,74]$. In these cases, the technical and economic viability of co-utilisation must be studied critically with attention paid to the influence of co-combustion on operational efficiency, pollutants formation, flue gas emissions, and ash related issues in order to meet the acceptable standards for energy, environment and financial profitability throughout its processing stages $[75,76]$.

\subsection{Pyrolysis}

Pyrolysis is the thermal decomposition or degradation of fuel without any oxidation agent in an inert (non-reactive) environment. It is used for producing bio-oil, solid char and gaseous fuel and referred to as incomplete gasification [77]. It involves the conversion of sewage sludge without air at moderate operating temperature $\left(350-600^{\circ} \mathrm{C}\right)$, although some pyrolysis reactors operating at higher temperature of up to $900{ }^{\circ} \mathrm{C}$ exist $[78,79]$. The output product of this process depends on the process temperature where char yield decreases with an increase in temperature. Therefore, high residence time of the fuel in the reactor at low temperature with slow heating rates promotes char production, while low or high residence time at high temperature promotes liquid and gas production 
respectively [80]. Nonetheless, application of this technology is mostly used to maximize liquid fuel yield. Figure 7 depicts the schematic of energy recovery from sludge pyrolysis, it can be seen that the drying requirements here are greater than for combustion with $<10 \%$ moisture tolerance in the input sludge fed into the reactor. The pyrolysis of sludge takes place in an inert environment at high temperatures, hence an external heat source (electric or thermal) would be required for supplying heat for the initiation of the reaction. The utilization of heat sourced from the partial combustion of biogas or bio-oil derived from the process itself has been critically explored for ensuring self-sustainability of pyrolysis, particularly in waste to energy applications. However, there are still various inefficiencies and thermodynamic considerations that have not been well accounted for in systems evaluation, leading to various design flaws in commercial scale plants and exaggerated optimism of self-sufficiency and efficiencies, despite lack of scientific evidence to back this claims [81]. Furthermore, research about the efficiency and cost effectiveness of sludge pyrolysis seems limited to already dried resources, rather than primary sludge. This is associated with the high energy and cost incurred from the drying process. The complexities involved in the pyrolysis reactor has been explained by previous studies which established that the decomposition of sewage sludge occurs in various stages due to the heterogeneous nature of the waste such that after the drying at $\leq 200$ ${ }^{\circ} \mathrm{C}$, the minor decomposition of decomposable organic matter, dead organisms and lipids follows at $200-300{ }^{\circ} \mathrm{C}$. This is followed by the decomposition of proteins, organic polymers and cellulosic constituents at temperatures $\leq 700{ }^{\circ} \mathrm{C}[82,83]$. These reaction stages occur simultaneously in reactors (mostly fluidised bed) due to the high heating rates and primarily produce heavy tars, light gases and chars at temperatures $<600^{\circ} \mathrm{C}$. Since maximization of liquid product is the desired goal of this technology, further secondary reactions are aided at temperatures around $600{ }^{\circ} \mathrm{C}$ such that the unstable primary products go through further pyrolysis to form secondary tar and gases. Other reaction progressions may result into the polymerization of some tars to produce coke. The difference in product distribution and yield characteristics mainly results from fuel characteristics (chemical compositions and particle size), reactor type and operating conditions (temperature, turbulence, residence time, pressure, feed rate and catalyst) as identified by previous studies [2]. These considerations, along with the intricate reaction chemistry, phase transitions and transport phenomena further complicates this energy recovery method. The condensation of the gaseous vapours from the reactor into bio-oil with high heating value of $\sim 33 \mathrm{MJ} / \mathrm{kg}$ occurs after cool down [84,85]. Pyrolytic products of bio-oil, biochar and non-condensable gases could all be utilized downstream which is the reason pyrolysis is gaining attention as a zero-waste energy recovery process. The bio-oil can be either used as combustion fuel for heat or electricity generation, refined to be used as liquid fuels or reformed to produce synthesis gas for chemicals production. Similarly, the biogas can be either burnt as fuel or upgraded to synthesis gas that can be processed for liquid fuel or chemical synthesis. Biochar, on the other hand has diverse application from direct combustion as solid fuel, adsorptive capability in catalyst applications and agricultural applications. Although the further use of char is promising, its feasibility is still dependent on its suitability for each usage with respect to energy content, heavy metals and nutrients content. As a result, recent research works have been focussed on optimisation of reactor conditions for maximizing energy recovery, minimising heavy metal emissions as well as the use of biochar as a value-added resource. As investigated by Yi et al. [86], the energy recovery from the use of sewage sludge as a solid fuel and other waste to energy technologies are crucial in the reduction of the greenhouse gas emissions from such wastes, if disposed.

The maximization of the bio-oil yield is the common aim of sewage sludge pyrolysis as the heating value is slightly higher than bio-oil from biomass. However, the bio-oil generated from sewage sludge has $>23 \%$ moisture content which diminishes the fuel quality by reducing energy density, flame temperature and causing deterrent combustion properties when used in engines in comparison to biomass-derived bio-oil $[87,88]$. In addition, the high fraction $(\sim 33 \%)$ of O-containing compounds in the oil significantly limits its thermal output and causes intrinsic instability of the bio-oils which prevents its use as commercial replacement for fuel oil but rather for chemical production [87]. According to 
literature [89-91], liquid yield is maximised between $450-550{ }^{\circ} \mathrm{C}$ such that lower temperatures would be inadequate for optimal breakdown of char while higher temperatures favour increase in gas yield due to thermal cracking of tar. Hence, minimisation of residence time has been adopted as an approach to prevent secondary reaction $[90,92]$. This technology is not suitable for wet sludge because of the influence of moisture on the reactor operating conditions (steam-rich atmosphere), oil quality and increase in non-condensable gases [93]. Interestingly, the use of microwave powered reactors has been studied to enhance the use of high moisture sludge with limited influence on product distribution with or without catalysts [94].

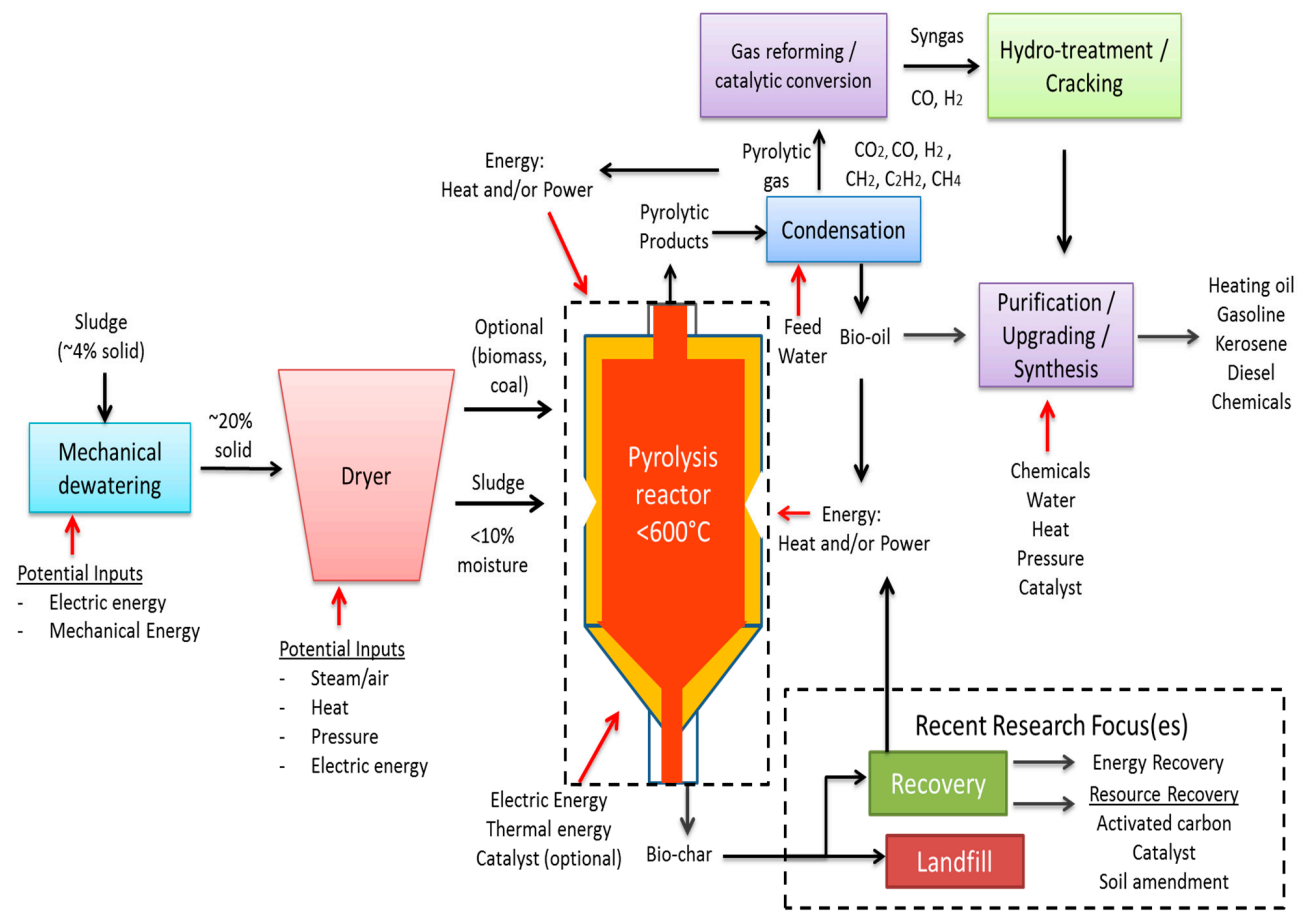

Figure 7. Schematic Representation of the Pyrolysis of Sludge.

Recent studies utilised various reactor types (e.g., batch, continuous, microwave, fluidized bed and horizontal furnace), operating conditions (e.g., temperature, time, power and catalyst) and fuel (e.g., primary, digested, wet sludge and blends) for optimising pyrolytic product distribution and their quality as seen in Table 4 which summarises results from past studies. The bio-oil yield from sewage sludge pyrolysis ranges from $14-57.5 \mathrm{wt} \%$ [95-105]. Pokorna et al. [105] reported a maximum bio-oil yield of $57.5 \mathrm{wt} \%$ with water content as low as $10 \mathrm{wt} \%$ when flash pyrolysis was conducted at $500{ }^{\circ} \mathrm{C}$ in a lab-scale semi-continuous reactor. Likewise, up to $48.5 \mathrm{wt} \%$ of bio-oil was reported when flash pyrolysis of dried primary sludge and anaerobically digested sludge was investigated by Alvarez et al. [87] in a conical spouted bed reactor. One of the benefits of the low temperatures for pyrolysis as explained by Jin et al. [97] is the retention of heavy metals in biochar which eliminates transfer of such elements to pyrolytic oil or gas and reduces the potential of toxic emissions. Also, studies by Lee et al. [106] confirmed that the stability of heavy metals and the crystallinity of inorganic compounds are increased by pyrolysis of sludge such that metal leaching ratio reduced to $<3.2 \%$ at $500{ }^{\circ} \mathrm{C}$. The use of acid pre-treatment and catalysts have been reported to have negligible or negative influence on the bio-oil yield $[94,99,107,108]$. However, these studies have also observed improvement in quality of the pyrolytic products with catalyst. The pyrolysis of wet sludge ( $>84 \mathrm{wt} \%$ moisture) was studied using a $900 \mathrm{~W}$ microwave reactor at $2.4 \mathrm{GHz}$ with maximum bio-oil yield of $20 \%$ after $30 \mathrm{~min}$ processing at $600{ }^{\circ} \mathrm{C}$ [95]. The potential for wet sludge usage directly in thermal reactors, makes microwave technologies highly attractive, however scaling up the technology is still a challenge. As a result, the use of various heating rates, catalysts and reaction temperatures on sewage sludge has been adopted for maximizing liquid products as investigated by various researchers [95-97]. 
Table 4. Summary of key research on pyrolysis of sewage sludge.

\begin{tabular}{|c|c|c|c|}
\hline Author(s) & Fuel types Investigated & Reactor Type Used & Observations \\
\hline Alvarez et al. [87] & $\begin{array}{l}\text { Sewage sludge }(0.5-3 \mathrm{~mm}) \\
\text { (Anaerobic digested and } \\
\text { thermally dried before use) }\end{array}$ & $\begin{array}{l}\text { Conical spouted bed reactor at } 450, \\
500 \text { and } 600^{\circ} \mathrm{C} \text { with }<100 \mathrm{~ms} \\
\text { residence time (fast pyrolysis) }\end{array}$ & $\begin{array}{l}\text { Bio-oil yields was } 44.8,48.5 \text { and } 45.4 \mathrm{wt} \% \text { at } 450,500 \text { and } 600{ }^{\circ} \mathrm{C} \text {. Liquid yield was } \\
\text { maximised at } 500{ }^{\circ} \mathrm{C} \text { due to low volatile residence time and lack of secondary } \\
\text { cracking reactions. Char and gas were highest at } 450^{\circ} \mathrm{C} \text { and } 600^{\circ} \mathrm{C} \text { respectively. The } \\
\text { fuel properties differ from hydrocarbon and biomass derived oils, hence more } \\
\text { suitable for chemical production. }\end{array}$ \\
\hline Jin et al. [97] & Sewage sludge & $\begin{array}{l}\text { Homemade pyrolysis and } \\
\text { carbonization furnace }\left(400-600^{\circ} \mathrm{C}\right) \\
\text { for } 60 \mathrm{~min}\end{array}$ & $\begin{array}{l}\text { Biochar yield decreased from } 60.6 \text { to } 53.1 \% \text { with increasing temperatures. High } \\
\text { concentration of heavy metals retained in biochar. Biochar has lower surface area in } \\
\text { comparison to other adsorbents due to pore blockages by tar. Decrease in the amount } \\
\text { of bioavailable heavy metals while oxidative and residual fractions increased which } \\
\text { indicates lower levels of ecological risks with biochar disposal or usage }\end{array}$ \\
\hline Gao et al. [96] & Dried sewage sludge & $\begin{array}{l}\text { Horizontal tubular furnace reactor }(2 \\
\mathrm{L} / \mathrm{min} \mathrm{N}_{2} \text { at } 450-650^{\circ} \mathrm{C} \text {. slow and } \\
\left.\text { fast pyrolysis at } 8 \text { and } 100^{\circ} \mathrm{C} / \mathrm{min}\right)\end{array}$ & $\begin{array}{l}\text { Fast Pyrolysis-Char yield reduced from } 47.07 \text { to } 29.96 \% \text { with increasing temperature } \\
\text { Tar yield increased to maximum }(46.14 \%) \text { at } 5500^{\circ} \mathrm{C} \text { and then decreased with further } \\
\text { increase in temperature. Gas yield increases with increase in temperature. } \\
\text { Slow Pyrolysis-Decrease in char ( } 33.24-53.6 \%) \text { and tar }(32.18-38.28 \%) \text { and increase } \\
\text { in gases }(14.24-28.64 \%) \text { due to secondary cracking reactions. }\end{array}$ \\
\hline Lin et al. [95] & $\begin{array}{c}\text { Wet sludge }(84.9 \pm 1.2 \mathrm{wt} \% \\
\text { water })\end{array}$ & $\begin{array}{l}\text { Multimode microwave reactor ( } 900 \\
\mathrm{~W}, 200 \mathrm{~mL} / \mathrm{min} \mathrm{N}_{2}, 400-800^{\circ} \mathrm{C} \text { for } \\
\qquad 30 \mathrm{~min} \text { ) }\end{array}$ & $\begin{array}{l}\text { Gas phase: } 15-29 \% \text {; Liquid phase: } 14-20 \% \text {; and } \\
\text { Solid fraction: } 57-69 \% \text {. The maximum yield and heating value (HV) of bio-oil was } \\
\text { obtained at } 600{ }^{\circ} \mathrm{C} \text { and the HV } 2.7 \text { times of the dried sludge cake. Microwave } \\
\text { processing is promising for sludge. }\end{array}$ \\
\hline Park et al. [104] & $\begin{array}{l}\text { Digested and dried sewage } \\
\text { sludge }\end{array}$ & $\begin{array}{l}\text { Fluidized bed reactor }(3 \mathrm{~kW}, 200 \\
\left.\mathrm{mL} / \mathrm{min} \mathrm{N}_{2}, 446-720^{\circ} \mathrm{C} \text { for } 30 \mathrm{~min}\right)\end{array}$ & $\begin{array}{c}\text { Maximum of } 54 \mathrm{wt} \% \text { of bio-oil was obtained with } \mathrm{HV} \text { of about } 2 \text { times that of the } \\
\text { dried sewage sludge } \\
\mathrm{HV} \text { of gas and char ranged from } 5-30 \text { and } 5-10 \mathrm{MJ} / \mathrm{Kg} \text {. The bio-oil has negligible } \\
\text { hazardous metals but has very high } \mathrm{N} \text { content. }\end{array}$ \\
\hline Pokorna et al. [105] & $\begin{array}{l}\text { Thickened excess activated } \\
\text { sludge (AKP), dewatered } \\
\text { digested sludge (DIG), and dried } \\
\text { excessive activated sludge } \\
\text { (OLDA) }\end{array}$ & $\begin{array}{l}\text { Semi-continuous lab scale flash } \\
\text { pyrolysis reactor at } 500{ }^{\circ} \mathrm{C}\end{array}$ & $\begin{array}{l}\text { Bio-oil yields varies between } 39.2-57.5 \% \text {. The water content of bio-oil varies between } \\
10.3-17 \% \text { based on the sludge type. HV ranged between } 23.9-29.0 \mathrm{MJ} / \mathrm{kg} \text { for bio-oil } \\
\text { and 5.2-10.6 MJ } / \mathrm{kg} \text { for char. }\end{array}$ \\
\hline Kim and Parker [107] & $\begin{array}{l}\text { Primary sewage sludge, } \\
\text { thickened waste activated sludge } \\
\text { and digested sludge bio-solids }\end{array}$ & $\begin{array}{l}\text { Cylindrical batch pyrolysis reactor at } \\
250-500^{\circ} \mathrm{C} \text { with zeolite as catalyst } \\
\text { and acid pre-treatment. }\end{array}$ & $\begin{array}{l}\text { Calorific value of } 32-42 \mathrm{MJ} / \mathrm{kg} \text { and } 7-23 \mathrm{MJ} / \mathrm{kg} \text { for bio-oil and char respectively. Oil } \\
\text { yield ranges between } 4-42 \% \text { with maximum at } 500^{\circ} \mathrm{C} \text { for primary sludge. Other } \\
\text { types of sludge generated maximum oil at } \sim 400^{\circ} \mathrm{C} \text {. Char yield varies between } \\
33-87 \% \text { with maximum at } 2500^{\circ} \mathrm{C} \text {. The use of zeolite reduces char yield but does not } \\
\text { impact the oil yield considerably. Pre-treatment did not enhance the bio-oil yield. } \\
\text { Most economically viable option is the use of primary sludge at } 500{ }^{\circ} \mathrm{C} \text {. }\end{array}$ \\
\hline Zhou et al. [99] & $\begin{array}{l}\text { Sewage sludge }(78 \% \text { water } \\
\text { content) }\end{array}$ & $\begin{array}{c}\text { Benchtop batch and continuous } \\
\text { microwave reactor }(1000 \mathrm{~W} \text { and } 2.45 \\
\left.\text { GHz at } 450-600^{\circ} \mathrm{C}\right) \text { with HZSM-5 } \\
\text { catalyst }\end{array}$ & $\begin{array}{l}\text { Bio-oil yield ranges from } 16.47-39 \mathrm{wt} \% \text { with maximum at } 550^{\circ} \mathrm{C} \text {. Char yield } \\
\text { decreased from } 62.26-32.98 \mathrm{wt} \% \text { with increasing temperature. The continuous reactor } \\
\text { increased bio-oil yields by } \sim 16 \% \text {. The use of HZSM-5 decreased the bio-oil generated } \\
\text { in both reactors. }\end{array}$ \\
\hline Fonts et al. [109] & $\begin{array}{l}\text { Digested and dried sewage } \\
\text { sludge }\end{array}$ & $\begin{array}{l}\text { Lab scale fluidized bed reactor at } \\
450-650^{\circ} \mathrm{C}, 3.5-5.5 \mathrm{~L} / \mathrm{min} \text { and feed } \\
\text { rate of } 3-6 \mathrm{~g} / \mathrm{min} \text { for } 75 \mathrm{~min}\end{array}$ & $\begin{array}{l}\text { Solid, liquid and gas yields are between } 46.1-63.0 \%, 23.4-40.7 \% \text { and } 7.3-27.9 \% \\
\text { respectively with maximum yield at } 450,550 \text { and } 650 \text {, respectively. The feed rate and } \\
\mathrm{N}_{2} \text { flow rate does not affect the liquid yield, low feed rate and } \mathrm{N}_{2} \text { flow rate enhances } \\
\text { solid yield. }\end{array}$ \\
\hline
\end{tabular}


Table 4. Cont

\begin{tabular}{|c|c|c|c|}
\hline Author(s) & Fuel types Investigated & Reactor Type Used & Observations \\
\hline Ischia et al. [108] & Sewage Sludge & $\begin{array}{l}\mathrm{TGA} \text { at } 1000^{\circ} \mathrm{C}, 10^{\circ} \mathrm{C} / \mathrm{min}(80 \\
\mathrm{mL} / \mathrm{min} \mathrm{He}) . \text { Clay catalyst. }\end{array}$ & $\begin{array}{l}52 \mathrm{wt} \% \text { mass reduction up to } 600{ }^{\circ} \mathrm{C} \text { with evolved gases mostly hydrocarbons. With } \\
\text { clay as catalyst, concentration of } \mathrm{CO} \text { reduced with higher } \mathrm{CO}_{2} \text {. }\end{array}$ \\
\hline Pedroza et al. [91] & Dried sewage sludge & $\begin{array}{l}\text { Continuous feed rotating cylinder } \\
\text { reactor }\left(500-600^{\circ} \mathrm{C}, 50 \mathrm{~mL} / \mathrm{min}\right. \\
\text { Nitrogen, } 4-22 \mathrm{~g} / \mathrm{min} \text { mass })\end{array}$ & $\begin{array}{l}\text { High temperature increases gas fraction with } 23.9 \% \text { gas yield at } 600{ }^{\circ} \mathrm{C} \text { with } 56 \% \\
\text { synthesis gas concentration. Decrease in char with increasing temperature with } \\
\text { lowest of } 52.7 \% \text { at } 600{ }^{\circ} \mathrm{C} \text {. Bio-oil yield was maximum at } 500{ }^{\circ} \mathrm{C} \text { with } 10.5 \% \text {. } \\
\text { Char yield reduces by } \sim 9 \mathrm{wt} \% \text { while gas yield increases by } \sim 9 \mathrm{wt} \% \text { with } 40 \mathrm{~min}\end{array}$ \\
\hline Gao et al. [98] & Dried sewage sludge & $\begin{array}{l}\text { Continuous feed screw reactor } \\
\left(500-800{ }^{\circ} \mathrm{C} ; 6-46 \mathrm{~min} \text { residence time; }\right. \\
\text { Nitrogen, } 4-100 \mathrm{~g} / \mathrm{min} \text { mass })\end{array}$ & $\begin{array}{l}\text { increase in residence time. Bio-oil yield increased by } \sim 3 \% \text { with } 17 \mathrm{~min} \text { increase but } \\
\text { decreased afterwards. Optimal residence time for char conversion and bio-oil } \\
\text { maximization was determined to be } 23 \text { min. Gas and char yield increases and } \\
\text { decreases with increase in temperature respectively while bio-oil increases till } 700{ }^{\circ} \mathrm{C} \\
\text { then decreased drastically at } 800{ }^{\circ} \mathrm{C} \text {. The ecological risk of char obtained remained } \\
\text { moderate in comparison to the fuel ash. }\end{array}$ \\
\hline Ma et al. [110] & $\begin{array}{l}\text { Dewatered high ash sludge } \\
\quad(88.10 \mathrm{wt} \% \text { moisture })\end{array}$ & $\begin{array}{l}\text { Microwave reactor at } 0.7-1 \mathrm{~kW} \text { with } \\
10 \mathrm{~mL} / \text { min Nitrogen }(\mathrm{SiC} \text {, graphite } \\
\text { and residue absorbent) }\end{array}$ & $\begin{array}{l}\text { Biogas (10.74-16.93\%), bio-oil (2.98-3.52\%) and biochar (78.27-84.30\%) yield with } \\
\text { various absorbents. Pyrolysis with SiC and graphite gave the highest biogas and } \\
\text { bio-oil yield respectively. Biochar and biogas yield reduced and increased with } \\
\text { increasing input power. }\end{array}$ \\
\hline Xie et al. [94] & Sewage sludge & $\begin{array}{l}\text { Microwave oven of } 750 \mathrm{~W} \text { at } 2.45 \\
\text { GHz with HZSM- } 5 \text { catalyst from } \\
450-600^{\circ} \mathrm{C}\end{array}$ & $\begin{array}{c}\text { Maximum yield of bio-oil was achieved at } 550^{\circ} \mathrm{C} \text {. The oil and gas yield are maximum } \\
\text { without the use of catalyst while char yield increased with catalyst loading. However, } \\
\text { the quality of bio-oil (lowest oxygen- and nitrogen-containing compounds) was } \\
\text { improved at catalyst to feed ratio of 2:1. }\end{array}$ \\
\hline Huang et al. [111] & $\begin{array}{l}\text { Dry sewage sludge cake and rice } \\
\text { straw }\end{array}$ & Single mode Microwave at $2.45 \mathrm{GHz}$ & $\begin{array}{l}\text { The use of rice straw enhanced microwave absorption and efficiency of the reaction. } \\
\text { The need for further study is required for establishing feasibility of microwave } \\
\text { co-pvrolysis. }\end{array}$ \\
\hline Chen et al. [112] & Dried Digested Sewage Sludge & $\begin{array}{l}\text { Fixed bed Tubular furnace, } 700 \\
\mathrm{~mL} / \mathrm{min} \mathrm{N}_{2}, 450{ }^{\circ} \mathrm{C}, 60 \mathrm{~min}\end{array}$ & $\begin{array}{c}\text { Maximum pyrolytic oil yield of } 10.19 \mathrm{wt} \% \text {. The heating rate, temperature, residence } \\
\text { time and nitrogen flow rate affects the yield. }\end{array}$ \\
\hline
\end{tabular}


However, the bio-oil yield is optimal between $500-600^{\circ} \mathrm{C}$ as observed in various studies $[94,98,99]$. The change in operating temperature, however influences the composition of the bio-oil in terms of the water, aromatic and aliphatic compounds. Regardless of the operating condition, char remains the highest product due the contribution of char and ash ( $~ 50 \mathrm{wt} \%)$ but offers advantages such as negligible pollutant emission in comparison to incineration because of its low operating temperature and inert atmosphere [98]. As a result, heavy metal emissions and their adverse impact is minimized. Notwithstanding, minimal concentration of some metal species like cadmium and mercury have been detected in pyrolytic oil at temperatures $<700{ }^{\circ} \mathrm{C}$ due to their low boiling points [100].

The high inorganic compounds in sewage sludge pyrolysis influences the reaction by reducing liquid yield and increasing solid residue due to hindrance of organic matter decomposition by some metal oxides $(\mathrm{CaO}, \mathrm{ZnO})$, and promotion of secondary reactions by catalytic species like transitional and alkali and alkaline earth metals [101]. The negative impact of these inorganic elements on the liquid yield establishes the need of pre-treatment process for removing some inorganic matters via leaching or rapid removal of char from the pyrolysis chamber during reaction. The solid char can be used further for heat generation via combustion, as an economic alternative as catalyst, and/or as heavy metal or organic contaminant store (by adsorption). All of which requires further consideration on more attractive and harmless application and/or disposal methods of this char [102]. This concern of heavy metals have been studied by others $[97,98,103]$ who established minimal vaporization of heavy metal during pyrolytic reaction conditions which was characterized by low concentrations of heavy metals in bio-oil and gas and high concentration in the resultant char at different operating temperatures. However, this heavy metal content in char still pose a huge challenge during utilisation or disposal of the biochar as mentioned in Figure 8 which assesses the current status of pyrolysis as a sludge to energy recovery method.

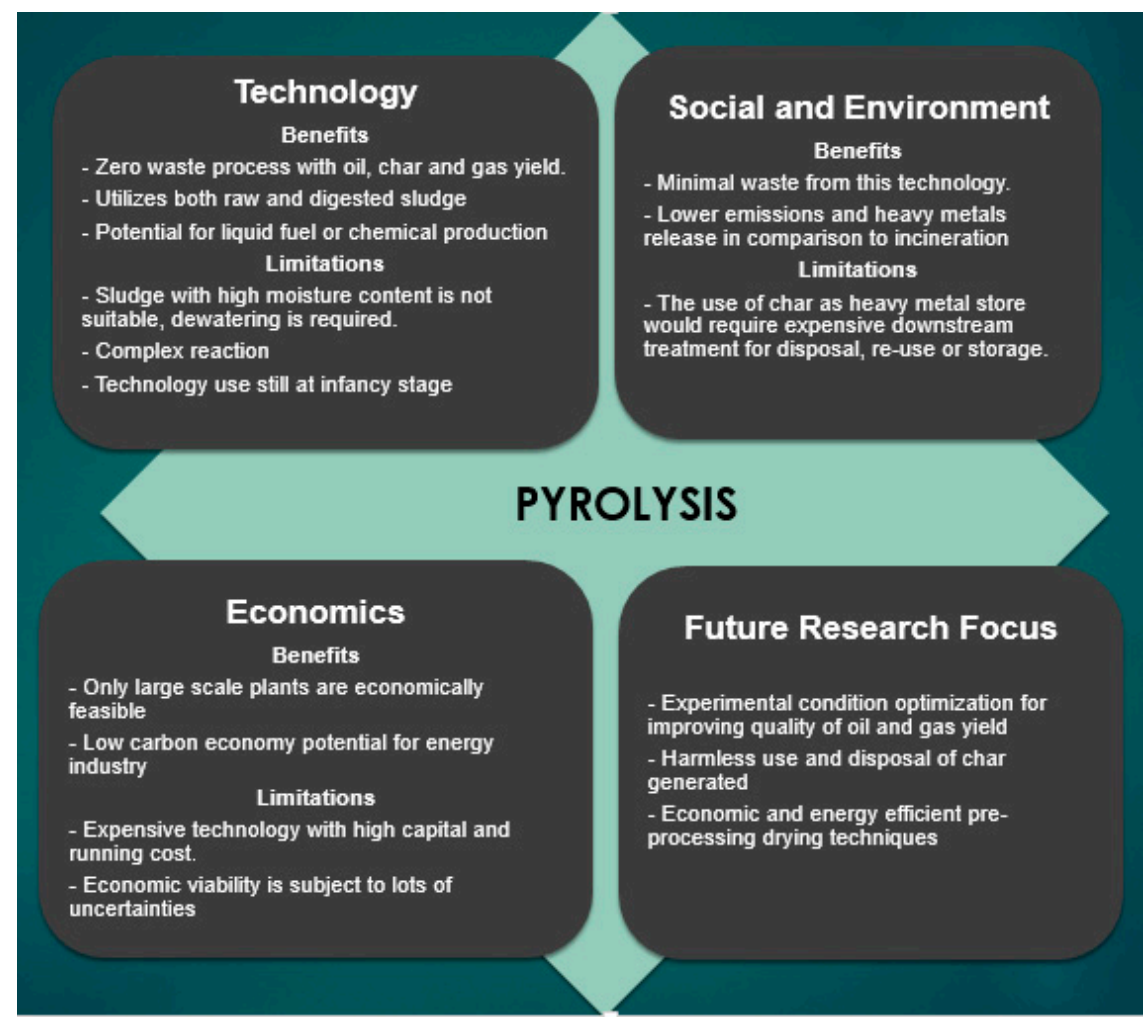

Figure 8. Technological, Socio-environmental and Economic Assessment of Pyrolysis for Sludge Processing.

Although the flue gas from this reaction requires less emissions/pollutant clean-up facilities, in comparison to incineration and anaerobic digestion, pyrolysis is a complex process and its economic viability remains dependent on ability to maximize efficiency and produce high valued oil, gas and char that can be furthered processed for heat, chemical and liquid fuels production. Pyrolysis is 
considered a zero waste technology and has high potential for sustainable energy that resolves all social, economic and environmental concerns but its use for sewage sludge processing is not well established and requires further research on treatments, operating conditions optimization and further minimization of heavy metal in liquid and gaseous products.

\subsection{Gasification}

The thermochemical conversion of sewage sludge's organic content into high value gases such as $\mathrm{H}_{2}$ and $\mathrm{CO}$ known as synthesis gas, as well as $\mathrm{CO}_{2}, \mathrm{CH}_{4}, \mathrm{H}_{2} \mathrm{O}$ and other hydrocarbons is the main basis for gasification. This reaction occurs in a partially oxidized reaction atmosphere at high temperature $\left(800-1000{ }^{\circ} \mathrm{C}\right)$ [113-115]. Gasification can be done using air, carbon dioxide, oxygen, steam, or mixtures of such gases. Past studies have identified that the gasifying agent has significant impact on the calorific value of the syngas obtained which ranges from 4-12 MJ/Nm with highest heating value is extracted from the oxy-gasification [116,117]. The product gas can be used directly for heating or electricity generation via heat engine or can be further processed for chemicals or liquid fuel synthesis as illustrated in Figure 9. This process is very similar to combustion with the exception of the lower moisture tolerance in the reactor $(<15 \mathrm{wt} \%)$ and the deficit in stoichiometric oxidants required for complete combustion. The main output from the reactor are gases and ash. As previously explained, depending on the chemical and mechanical properties, as well as heavy metal contents, the ash generated from this process can be either disposed of at the landfill or reused in agricultural or construction applications. The product gases requires further processing and clean-up for either use in heat and electricity generation or upgrading of synthesis gas for liquid fuels and chemicals synthesis.

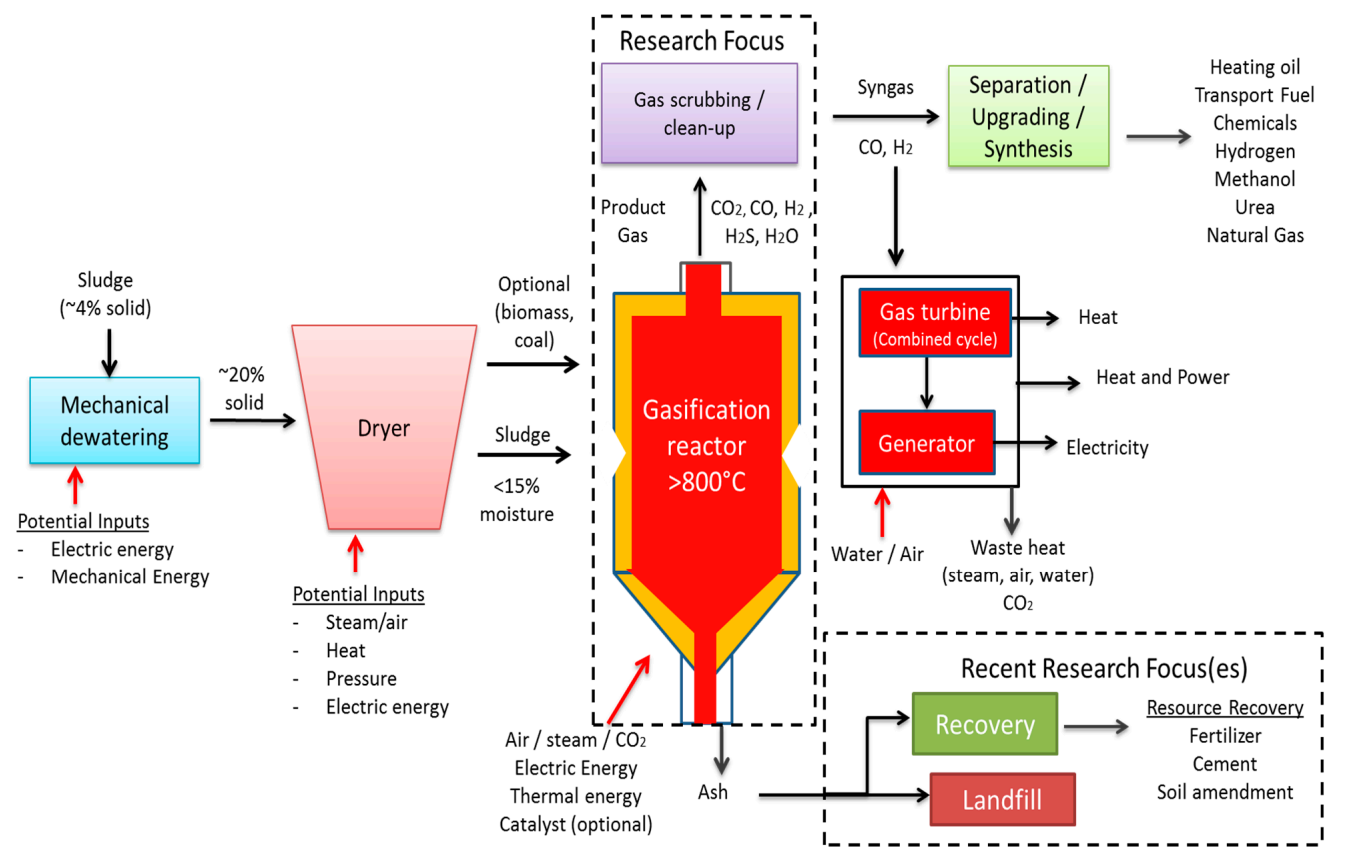

Figure 9. Schematic Representation of the Gasification of Sludge.

Gasification reaction can be divided into four sub-stages which are drying of sample $\left(70-200{ }^{\circ} \mathrm{C}\right)$, devolatilsation $\left(350-600^{\circ} \mathrm{C}\right)$, oxidation of volatiles and char gasification. Hence, it can also be termed as an incomplete combustion or extended pyrolysis reaction in which gas-solid, gas-gas and liquid cracking reactions are required in order to maximize the gaseous product yield.

The use of in-situ drying is only ideal for samples with low moisture content $(<15 \mathrm{wt} \%)[118,119]$. After the drying stage, the pyrolysis of the samples is done for generating volatiles and char that can be fully oxidized to drive the other reaction stages. Therefore the oxidation stage (with temperatures up to $1200{ }^{\circ} \mathrm{C}$ ) produces heat to run the gasification, pyrolysis and drying stage. Finally, the high temperature reduction of the char produced from pyrolysis generates light hydrocarbon gases in the 
fourth stage. The various reaction mechanisms affects the final product composition. The position of these sub-stages in the gasifier immensely affects the flow of gasifying agent, reaction process and operating efficiency, thereby becoming a deciding factor in the choice of reactors. There are three main types of gasifiers-fixed bed downdraft, fixed bed updraft and fluidized bed gasifier and detailed comparison can be found elsewhere $[78,120]$. In summary, the fixed bed alignment involves a flow of gasifying agent and heat up or down the reactor chambers to activate the drying, pyrolysis and gasifying stages consecutively. This leads to efficiency reduction and shorter residence time (particularly for char oxidation which is the rate-limiting step) in comparison to the fluidized bed that allows instantaneous occurresnce of all sub-stages which allows completion of the gasification process [121]. The reactor type also affects the tar and pollutant concentration in the product which hinders the efficiency of the process.

Table 5 summarises past studies on sewage sludge gasification with emphasis on different gasifying agents, reaction conditions, and catalyst use. Their results emphasizes the dependence of the end product on the sludge properties and the experimental conditions. Interestingly, the parametric considerations in sewage sludge gasification are mostly operating conditions such as equivalence ratio (ER), gas residence time, catalytic influences and operating temperature. The optimization of these factors are required for maximizing gas yield, enhancing gas quality, minimizing tar yield and increasing reaction efficiency. The reaction of sewage sludge with low $(<0.2)$ or high $(>0.5)$ equivalence ratio results in low gasification efficiency. Lower ER promotes incomplete gasification with high liquid tar and solid char fractions as end product whereas higher ER leads to a well oxidized environment that enhances complete combustion of a higher fraction of the char and tar, thereby generating more $\mathrm{CO}_{2}, \mathrm{H}_{2} \mathrm{O}$ and heat energy at the expense of synthesis gas and their calorific value [122-124]. This has been reported by others who studied influence of ER on the tar and syngas yield such that tar content decreased, syngas yield reduced at high ER [125-127]. Their findings deduced an optimal ER between $0.2-0.4$ for maximizing the production of $\mathrm{CO}, \mathrm{H}_{2}, \mathrm{CH}_{4}$ and other light hydrocarbons and increasing efficiency. As briefly mentioned earlier, the impact of residence time is crucial in ensuring complete gasification, hence a longer residence time of the gas would allow more char conversion to take place in the reactor [128]. This would also enhance cracking of tar, heavier volatiles and steam reforming which improves the quality and quantity of produced syngas. Nipattummakul et al. [129] established that gaseous product of sludge gasification increases with increasing temperatures for maximising synthesis gas yields. Similarly, the adoption of various catalysts (nickel, dolomite, zeolite, olivine and alumina) have been studied for improving gasification of sewage sludge, particularly for reducing tar content $[113,130,131]$. It was observed that dolomite was quite effective in eliminating tar yield and the combination of dolomite with activated carbon as bed material maximized $\mathrm{H}_{2}$ yield [130,132]. Roche et al. [113] reported $>20 \%$ increase in hydrogen yield and high reductions in the tar content of the gasifier outputs by the use of dolomite. Similar observations have been detected using $\mathrm{Ca}-$, $\mathrm{Fe}-$ and $\mathrm{Ni}-$ based catalyst for enhancing char gasification, methane reforming and tar cracking reactions $[133,134]$. These catalysts have also been established to have pollutant reduction properties [133]. The use of nickel based catalyst have indicated high tar reduction and lower NOx formation, however the deactivation of such catalyst at high temperatures from coke deposition remains a challenge $[131,135]$. The integration of an intermediate torrefaction inter-stage between drying and gasification has been proposed for the removal of a fraction of Nitrogen content and minimisation of NOx emission generated from the subsequent use of the product stream (gases) from the gasifier [29]. Finally, the influence of the bed temperature on the distribution of yields, gas quality and process efficiency have been previously studied such that lower temperatures favour tar and char production while higher temperatures favour gas yield and overall efficiency of process $[123,131,136]$. This temperature must not only increase the quantity but also the quality of syngas generated while ensuring that the tar reduction is maximised at higher temperatures [137]. In addition, this high temperature must be well considered to avoid clinker formation. 
Table 5. Summary of key research on gasification of sewage sludge.

\begin{tabular}{|c|c|c|c|}
\hline Author(s) & Fuel Types Investigated & Reactor Type Used & Observations \\
\hline Choi et al. [133] & Digested sewage sludge & $\begin{array}{l}\text { Three stage gasifier (auger }\left(650^{\circ} \mathrm{C}\right), \\
\text { fluidized bed }\left(815^{\circ} \mathrm{C}\right) \text { and tar cracking } \\
\left(815^{\circ} \mathrm{C}\right) \text { reactors connected serially), } \\
\text { gasifying agent- } \text { pre-heated air, } \\
\text { Catalyst-activated carbon, ER- } 0.3\end{array}$ & $\begin{array}{l}\text { The use of activated carbon increase syngas yield by } 12 \% \text {, while reducing } \\
\text { tar, hydrogen sulphide and ammonia content in the syngas. In addition, } \\
\text { the carbon conversion and tar removal efficiency increased by } 10 \text { and } 26 \% \\
\text { respectively. The use of Fe- and Ni-impregnated activated carbon reduced } \\
\text { the hydrogen sulphide and ammonia respectively. Increasing the } \\
\text { gasification time }(\sim 8 \mathrm{~h}) \text { effectively removed tar in output. }\end{array}$ \\
\hline Roche et al. [113] & Dried Sludge & $\begin{array}{l}\text { Laboratory scale fluidized bed gasifier } \\
\left(800^{\circ} \mathrm{C}\right), \text { gasifying agent-air }+ \text { steam, } \\
\text { ER-0.3, Catalyst— dolomite, feed } \\
\text { rate- } 110-322 \mathrm{~kg} / \mathrm{h} \mathrm{m}^{2}\end{array}$ & $\begin{array}{l}\text { Different feed rate influenced the quality and composition of the tar } \\
\text { generated. Higher feed rate decreased syngas yield while increasing tar } \\
\text { content while lower feed rate maximized } \mathrm{H}_{2} \text { and } \mathrm{CO} \text { in product. The use } \\
\text { of dolomite enhanced tar removal efficiency to } \sim 71 \% .20-36 \% \text { increase in } \\
\qquad \mathrm{H}_{2} \text { yield with dolomite. }\end{array}$ \\
\hline $\begin{array}{l}\text { Nipattummakul et } \\
\text { al. [131] }\end{array}$ & Solar dried sewage sludge & $\begin{array}{l}\text { Laboratory scale fixed bed gasifier } \\
\left(700-1000{ }^{\circ} \mathrm{C}\right), \text { gasifying agent-steam } \\
(3 \mathrm{~g} / \mathrm{min})\end{array}$ & $\begin{array}{l}\text { Char gasification, } \mathrm{H}_{2} \text { and } \mathrm{CO} \text { content of the producer gas increased with } \\
\text { increasing temperature. Energy conversion efficiency was maximum at } \\
1000^{\circ} \mathrm{C} \text {. }\end{array}$ \\
\hline Manyà et al. [138] & Digested sewage sludge & $\begin{array}{l}\text { Laboratory scale fluidized bed gasifier } \\
\left(750-850^{\circ} \mathrm{C}\right) \text {, gasifying agent-air, } \\
\text { ER-0.25-0.35, alumina bed }\end{array}$ & $\begin{array}{l}\text { The heating value and cold gas efficiency increased with increasing } \\
\text { temperature, attributed to steam reforming and cracking of tar. The gas } \\
\text { yield increased with increasing ER. } \mathrm{H}_{2} \text { content of syngas increases with } \\
\text { the alumina bed. }\end{array}$ \\
\hline Chen et al. [134] & Sewage sludge & $\begin{array}{l}\text { Laboratory scale fixed bed gasifier } \\
\left(650-850^{\circ} \mathrm{C}\right), \text { gasifying agent-steam } \\
(0.2 \mathrm{~g} / \mathrm{min}) \text {, Catalyst-calcium } \\
\text { oxide }(\mathrm{CaO}), \mathrm{Ni} \text { - and Fe-impregnated } \\
\mathrm{CaO}\end{array}$ & $\begin{array}{l}\text { Without the } \mathrm{CaO} \text { sorbents, hydrogen fraction and overall syngas yield } \\
\text { increases with increase temperature. The use of } \mathrm{CaO} \text { at lower } \\
\text { temperatures increased the } \mathrm{H}_{2} \text { fraction by enhancing tar cracking, } \\
\text { however } \mathrm{CaO} \text { with higher temperatures, the } \mathrm{H}_{2} \text { fraction reduced while } \\
\mathrm{CO}_{2} \text { increased. Though carbon conversion efficiency and cold gas } \\
\text { efficiency increased with } \mathrm{CaO} \text { use, it had negligible influence on char } \\
\text { gasification but on tar cracking. The impregnation of metals improved } \\
\text { methane reforming and char conversion. }\end{array}$ \\
\hline Lee et al. [139] & Dried sewage sludge & $\begin{array}{l}\text { Laboratory scale gasifier }\left(1000^{\circ} \mathrm{C}\right) \\
\text { gasifying agent—steam }(2.5-20 \mathrm{~g} / \mathrm{min})\end{array}$ & $\begin{array}{c}\text { Higher reaction temperature improved water gas shift reaction rates, } \\
\text { hence } \mathrm{CO}_{2} \text { and } \mathrm{H}_{2} \text { generation rates increased at the expense of } \mathrm{CO} \text { and } \\
\mathrm{CH}_{4} \text { with time. Increase in steam flow rate increased the syngas } \\
\text { generation rates at lower residence time. Carbon conversion is enhanced } \\
\text { with higher steam flow rate. }\end{array}$ \\
\hline Freda et al. [140] & Oven-dried sewage Sludge & $\begin{array}{l}\text { Bench scale rotary Kiln gasifier, } \\
\quad 750-850^{\circ} \mathrm{C}, \text { ER } 0.05-0.24\end{array}$ & $\begin{array}{l}\text { Producer gas of higher heating value was obtained at temperatures of } \\
800-850^{\circ} \mathrm{C} \text { and ER of } 0.15-0.24 \text {. Maximum cold gas efficiency of } 67 \% \text { was } \\
\text { obtained at } 850^{\circ} \mathrm{C} \text { with ER of } 0.16\end{array}$ \\
\hline
\end{tabular}


Nonetheless, the main challenges of sludge gasification are ash related issues due to the high content of inorganic constituents, tar minimisation and sludge composition (moisture, heavy metals, nitrogen and sulphur). The high content of ash in sewage sludge has a lot of adverse influence on gasifier operation, specifically sintering, agglomeration and clinker formation which leads to frequent shut down and maintenance of the reactor $[118,141]$. Furthermore, low ash fusion temperature also leads to blockage of the fuel flow which reduces the heat transfer potential and gas quality [125]. In addition, the probable volatization of gas phase compounds of the toxic inorganic elements like heavy metals at high temperatures $\left(750-1100{ }^{\circ} \mathrm{C}\right)$ results in deposition [142-145].

Nonetheless, gasification also helps with fixing heavy metals such as lead, chromium and nickel and reducing volatility of such compounds in residual ash [146-148]. The presence of tar in the product distribution presents a two-way issue in sludge gasification. At first, tar generated is related to reduction in gaseous product, condensation of such tar leads to clogging, fouling and other inefficient downstream issues. Secondly, the need for tar removal from the syngas is a necessity which must be done either inside the gasifier (experimental conditions optimisation or catalyst) and/or after the gasifier (post-reaction clean up using scrubbers). These processes leads to additional capital and operational costs but the external clean-up method is the most expensive $[149,150]$. The use of fuel blends for gasification was also studied for the maximization of hydrogen and synthesis gas yield [151]. Finally, the impact of fuel properties such as moisture content results in promotion of tar generation and additional energy requirements for drying the sludge. This affects the operation of the reactor, product distribution and the quality of the product gas. Also, the high nitrogen and sulphur content promotes ammonia, hydrogen cyanide and hydrogen sulphide formation which are toxic pollutants during the operation of the gasifier. The evaluation summary of this technology is depicted in Figure 10.

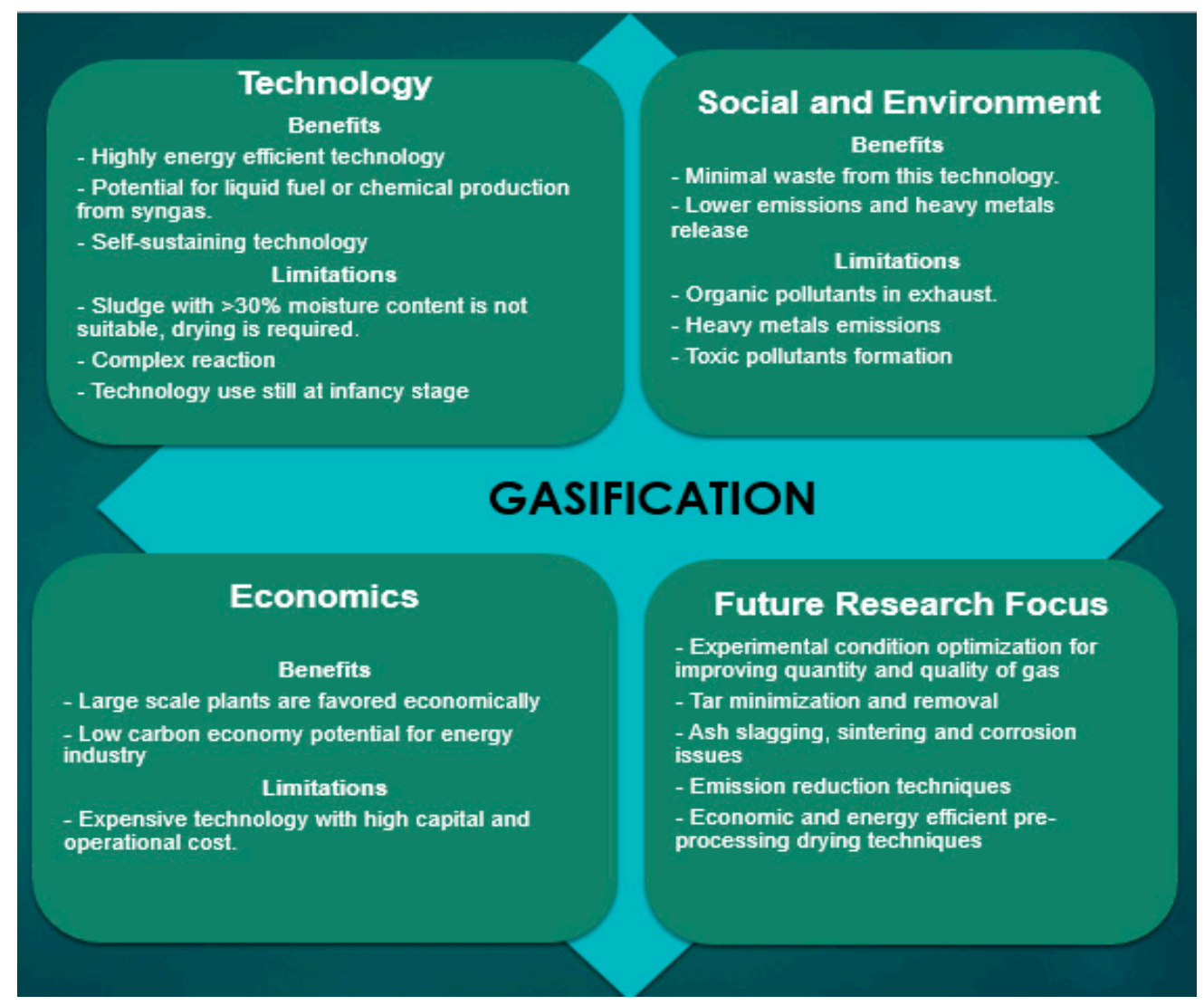

Figure 10. Technological, Socio-environmental and Economic Assessment of Gasification for Sludge Processing. 


\section{Conclusions and Future Perspectives}

This review work identifies the potential of municipal sludge as an energy feedstock. However, the complex composition of this resource remains its main limitation due to high moisture, ash, toxic heavy metals and organic contaminants which influences the safety of final products, increases energy/resource requirements, reduces the process efficiency and increases the overall cost of technology. The poor conversion efficiencies, long reaction time, adverse environmental impacts of digestates associated with anaerobic digestion are a major constraint in terms of cost and environmental sustainability but this is still the most appealing technology till date due to its low capital costs and lack of drying requirements. Although, these benefits may be offset by the cost and availability of resource needed for various pre-/post- or inter-stage treatment methods used for improving its conversion efficiencies. In comparison, combustion, pyrolysis and gasification technologies requires energy-intensive drying, expensive emission control, ash disposal or reuse strategies, and further downstream gas treatment for pollutant mitigation. These drawbacks increase the complexities, investment costs and reduce the energy conversion efficiency of these technologies. This has drawn attention to technologies such as microwave reactors which have shown some tolerance for sludge with moderately high moisture contents, but these systems have scale-up issues and their energy conversion efficiency is low. All considered technologies in this work show the need further research and development into co-utilization of sludge, operating condition optimization and effective technology scale-up for maximizing energy recovered while reducing cost and emissions.

An interesting observation is the lack of data to accurately back the high efficiency of most pyrolysis and gasification systems as they fail to account for the energy intensive pre-processing stage which offsets a considerable fraction of the recovered energy and could lead to negative energy balance. As a result, innovative pathways and research using these technologies commercially are required such as coupling of biochemical and thermochemical systems to optimise energy recovery. This could be easily conceptualised as an integrated biorefinery approach which can be designed appropriately for the maximization of energy outputs to reduce adverse environmental impacts. Regardless, all these processes must be tailored to suit individual locations and would require in-depth technical, economic and life cycle assessment for determining their sustainability in the low carbon future.

Author Contributions: Conceptualization, J.O. and K.S.; methodology, J.O. and Y.G.; resources, J.O., Y.G and X.L.; writing—original draft preparation, J.O.; writing_review and editing, J.O, K.S., X.L., Y.G. and T.W.; supervision, T.W.; project administration, K.S. and T.W.; funding acquisition, K.S. and T.W.

Funding: The scientific work was supported by the National Natural Science Foundation of China (51606106), Ningbo Natural Science Foundation (2017A610233), Ningbo Municipal Key Laboratory on Clean Energy Conversion Technologies, and the National Key R\&D Program of China (2017YFB0602602 and 2017YFC0210400).

Conflicts of Interest: The authors declare no conflict of interest.

\section{References}

1. Seiple, T.E.; Coleman, A.M.; Skaggs, R.L. Municipal wastewater sludge as a sustainable bioresource in the United States. J. Environ. Manag. 2017, 197, 673-680. [CrossRef] [PubMed]

2. Syed-Hassan, S.S.A.; Wang, Y.; Hu, S.; Su, S.; Xiang, J. Thermochemical processing of sewage sludge to energy and fuel: Fundamentals, challenges and considerations. Renew. Sustain. Energy Rev. 2017, 80, 888-913. [CrossRef]

3. Cieślik, B.M.; Namieśnik, J.; Konieczka, P. Review of sewage sludge management: Standards, regulations and analytical methods. J. Clean. Prod. 2015, 90,1-15. [CrossRef]

4. Magdziarz, A.; Dalai, A.K.; Koziński, J.A. Chemical composition, character and reactivity of renewable fuel ashes. Fuel 2016, 176, 135-145. [CrossRef]

5. Harrison, E.Z.; Oakes, S.R.; Hysell, M.; Hay, A. Organic chemicals in sewage sludges. Sci. Total Environ. 2006, 367, 481-497. [CrossRef] [PubMed]

6. Mulchandani, A.; Westerhoff, P. Recovery opportunities for metals and energy from sewage sludges. Bioresour. Technol. 2016, 215, 215-226. [CrossRef] [PubMed] 
7. Chan, W.P.; Wang, J.-Y. Comprehensive characterisation of sewage sludge for thermochemical conversion processes-Based on Singapore survey. Waste Manag. 2016, 54, 131-142. [CrossRef] [PubMed]

8. Vaxelaire, J.; Cézac, P. Moisture distribution in activated sludges: A review. Water Res. 2004, 38, $2215-2230$. [CrossRef] [PubMed]

9. Winkler, M.K.H.; Bennenbroek, M.H.; Horstink, F.H.; van Loosdrecht, M.C.M.; van de Pol, G.J. The biodrying concept: An innovative technology creating energy from sewage sludge. Bioresour. Technol. 2013, 147, 124-129. [CrossRef] [PubMed]

10. Mills, N.; Pearce, P.; Farrow, J.; Thorpe, R.B.; Kirkby, N.F. Environmental \& economic life cycle assessment of current \& future sewage sludge to energy technologies. Waste Manag. 2014, 34, 185-195. [CrossRef]

11. Lee, I.-S.; Parameswaran, P.; Rittmann, B.E. Effects of solids retention time on methanogenesis in anaerobic digestion of thickened mixed sludge. Bioresour. Technol. 2011, 102, 10266-10272. [CrossRef] [PubMed]

12. Xu, C.; Chen, W.; Hong, J. Life-cycle environmental and economic assessment of sewage sludge treatment in China. J. Clean. Prod. 2014, 67, 79-87. [CrossRef]

13. Włodarczyk-Makuła, M. Persistence of two-, three- and four-ring of PAHs in sewage sludge deposited in different light conditions. Desalin. Water Treat. 2016, 57, 1184-1199. [CrossRef]

14. Ding, H.H.; Chang, S.; Liu, Y. Biological hydrolysis pretreatment on secondary sludge: Enhancement of anaerobic digestion and mechanism study. Bioresour. Technol. 2017, 244, 989-995. [CrossRef] [PubMed]

15. Tsai, W.-T. An Analysis of the Use of Biosludge as an Energy Source and Its Environmental Benefits in Taiwan. Energies 2012, 5, 3064-3073. [CrossRef]

16. Raheem, A.; Sikarwar, V.S.; He, J.; Dastyar, W.; Dionysiou, D.D.; Wang, W.; Zhao, M. Opportunities and challenges in sustainable treatment and resource reuse of sewage sludge: A review. Chem. Eng. J. 2018, 337, 616-641. [CrossRef]

17. Ruffino, B.; Campo, G.; Cerutti, A.; Zanetti, M.C.; Scibilia, G.; Lorenzi, E.; Genon, G. Enhancement of waste activated sludge (WAS) anaerobic digestion by means of pre- and intermediate treatments. In Proceedings of the International Conference on Sustainable Solid Waste Management, Limassol, Cyprus, 21-24 June 2017.

18. Nielsen, H.B.; Thygesen, A.; Thomsen, A.B.; Schmidt, J.E. Anaerobic digestion of waste activated sludge-Comparison of thermal pretreatments with thermal inter-stage treatments. J. Chem. Technol. Biotechnol. 2011, 86, 238-245. [CrossRef]

19. Valo, A.; Carrère, H.; Delgenès, J.P. Thermal, chemical and thermo-chemical pre-treatment of waste activated sludge for anaerobic digestion. J. Chem. Technol. Biotechnol. 2004, 79, 1197-1203. [CrossRef]

20. Sivagurunathan, P.; Zhen, G.; Kim, S.; Saratale, G.D. A review on bio-electrochemical systems (BESs) for the syngas and value added biochemicals production. Chemosphere 2017, 177, 84-92. [CrossRef]

21. Meegoda, J.N.; Li, B.; Patel, K.; Wang, L.B. A Review of the Processes, Parameters, and Optimization of Anaerobic Digestion. Int. J. Environ. Res. Public Health 2018, 15, 2224. [CrossRef]

22. Roubík, H.; Mazancová, J.; Le Dinh, P.; Dinh Van, D.; Banout, J. Biogas Quality across Small-Scale Biogas Plants: A Case of Central Vietnam. Energies 2018, 11, 1794. [CrossRef]

23. Pant, D.; Singh, A.; Bogaert, G.V.; Olsen, S.I.; Nigam, P.S.; Dielsa, L.; Vanbroekhoven, K. Bioelectrochemical systems (BES) for sustainable energy production and product recovery from organic wastes and industrial wastewaters. RSC Adv. 2012, 2, 1248-1263. [CrossRef]

24. Jong, E.; Jungmeier, G. Chapter 1-Biorefinery Concepts in Comparison to Petrochemical Refineries. Ind. Biorefineries White Biotechnol. 2015, 3-33. [CrossRef]

25. Zacharof, M.-P. The filtration characteristics of anaerobic digester effluents employing cross flow ceramic membrane microfiltration for nutrient recovery. Desalination 2014, 341, 27-37. [CrossRef]

26. Gerardo, M.L.; Zacharof, M.-P.; Lovitt, R.W. Strategies for the recovery of nutrients and metals from anaerobically digested dairy farm sludge using cross-flow microfiltration. Water Res. 2013, 47, 4833-4842. [CrossRef] [PubMed]

27. Zacharof, M.-P.; Mandale, S.J.; Williams, P.M.; Lovitt, R.W. Nanofiltration of treated digested agricultural wastewater for recovery of carboxylic acids. J. Clean. Prod. 2016, 112, 4749-4761. [CrossRef]

28. Gottumukkala, L.D.; Haigh, K.; Collard, F.; Rensburg, E.V.; Görgens, J. Opportunities and prospects of biorefinery-based valorisation of pulp and paper sludge. Bioresour. Technol. 2016, 215, 37-49. [CrossRef] [PubMed] 
29. Tic, W.J.; Guziałowska-Tic, J.; Pawlak-Kruczek, H.; Woźnikowski, E.; Zadorożny, A.; Niedźwiecki, Ł.; Wnukowski, M.; Krochmalny, K.; Czerep, M.; Ostrycharczyk, M.; et al. Novel Concept of an Installation for Sustainable Thermal Utilization of Sewage Sludge. Energies 2018, 11, 748. [CrossRef]

30. Aryal, N.; Kvist, T. Alternative of Biogas Injection into the Danish Gas Grid System-A Study from Demand Perspective. Chem. Eng. 2018, 2, 43. [CrossRef]

31. Guo, L.; Zhang, Z.; Gao, M.; She, Z.; Zhao, Y.; Guo, Y.; Sun, J. Comparison of thermophilic bacteria and alkyl polyglucose pretreatment on two-stage anaerobic digestion with waste sludge: Biogas production potential and substrate metabolism process. Bioresour. Technol. 2018, 249, 694-703. [CrossRef]

32. Devlin, D.C.; Esteves, S.R.R.; Dinsdale, R.M.; Guwy, A.J. The effect of acid pretreatment on the anaerobic digestion and dewatering of waste activated sludge. Bioresour. Technol. 2011, 102, 4076-4082. [CrossRef] [PubMed]

33. Riau, V.; De la Rubia, M.A.; Pérez, M. Upgrading the temperature-phased anaerobic digestion of waste activated sludge by ultrasonic pretreatment. Chem. Eng. J. 2015, 259, 672-681. [CrossRef]

34. Martín, M.Á.; González, I.; Serrano, A.; Siles, J.Á. Evaluation of the improvement of sonication pre-treatment in the anaerobic digestion of sewage sludge. J. Environ. Manag. 2015, 147, 330-337. [CrossRef] [PubMed]

35. Houtmeyers, S.; Degrève, J.; Willems, K.; Dewil, R.; Appels, L. Comparing the influence of low power ultrasonic and microwave pre-treatments on the solubilisation and semi-continuous anaerobic digestion of waste activated sludge. Bioresour. Technol. 2014, 171, 44-49. [CrossRef] [PubMed]

36. Zhen, G.; Lu, X.; Kato, H.; Zhao, Y.; Li, Y.-Y. Overview of pretreatment strategies for enhancing sewage sludge disintegration and subsequent anaerobic digestion: Current advances, full-scale application and future perspectives. Renew. Sustain. Energy Rev. 2017, 69, 559-577. [CrossRef]

37. Lin, Y.; Wang, D.; Wu, S.; Wang, C. Alkali pretreatment enhances biogas production in the anaerobic digestion of pulp and paper sludge. J. Hazard. Mater. 2009, 170, 366-373. [CrossRef] [PubMed]

38. Weemaes, M.; Grootaerd, H.; Simoens, F.; Verstraete, W. Anaerobic digestion of ozonized biosolids. Water Res. 2000, 34, 2330-2336. [CrossRef]

39. Takashima, M.; Tanaka, Y. Acidic thermal post-treatment for enhancing anaerobic digestion of sewage sludge. J. Environ. Chem. Eng. 2014, 2, 773-779. [CrossRef]

40. Ebenezer, A.V.; Arulazhagan, P.; Adish Kumar, S.; Yeom, I.-T.; Rajesh Banu, J. Effect of deflocculation on the efficiency of low-energy microwave pretreatment and anaerobic biodegradation of waste activated sludge. Appl. Energy 2015, 145, 104-110. [CrossRef]

41. Coelho, N.M.G.; Droste, R.L.; Kennedy, K.J. Evaluation of continuous mesophilic, thermophilic and temperature phased anaerobic digestion of microwaved activated sludge. Water Res. 2011, 45, 2822-2834. [CrossRef]

42. Appels, L.; Houtmeyers, S.; Degrève, J.; Van Impe, J.; Dewil, R. Influence of microwave pre-treatment on sludge solubilization and pilot scale semi-continuous anaerobic digestion. Bioresour. Technol. 2013, 128, 598-603. [CrossRef] [PubMed]

43. Wilson, C.A.; Tanneru, C.T.; Banjade, S.; Murthy, S.N.; Novak, J.T. Anaerobic Digestion of Raw and Thermally Hydrolyzed Wastewater Solids Under Various Operational Conditions. Water Environ. Res. 2011, 83, 815-825. [CrossRef] [PubMed]

44. Pilli, S.; More, T.; Yan, S.; Tyagi, R.D.; Surampalli, R.Y. Anaerobic digestion of thermal pre-treated sludge at different solids concentrations-Computation of mass-energy balance and greenhouse gas emissions. J. Environ. Manag. 2015, 157, 250-261. [CrossRef] [PubMed]

45. Xue, Y.; Liu, H.; Chen, S.; Dichtl, N.; Dai, X.; Li, N. Effects of thermal hydrolysis on organic matter solubilization and anaerobic digestion of high solid sludge. Chem. Eng. J. 2015, 264, 174-180. [CrossRef]

46. Cao, Y.; Pawlowski, A. Sewage sludge-to-energy approaches based on anaerobic digestion and pyrolysis: Brief overview and energy efficiency assessment. Renew. Sustain. Energy Rev. 2012, 16, 1657-1665. [CrossRef]

47. Morales-Polo, C.; Cledera-Castro, M.M.; Moratilla Soria, B.Y. Reviewing the Anaerobic Digestion of Food Waste: From Waste Generation and Anaerobic Process to Its Perspectives. Appl. Sci. 2018, 8, 1804. [CrossRef]

48. Keucken, A.; Habagil, M.; Batstone, D.; Jeppsson, U.; Arnell, M. Anaerobic Co-Digestion of Sludge and Organic Food Waste-Performance, Inhibition, and Impact on the Microbial Community. Energies 2018, 11, 2325. [CrossRef]

49. Guimarães, C.S.; Maia, D.R.S.; Serra, E.G. Construction of Biodigesters to Optimize the Production of Biogas from Anaerobic Co-Digestion of Food Waste and Sewage. Energies 2018, 11, 870. [CrossRef] 
50. Wu, M.-H.; Lin, C.-L.; Huang, W.-C.; Chen, J.-W. Characteristics of pervious concrete using incineration bottom ash in place of sandstone graded material. Constr. Build. Mater. 2016, 111, 618-624. [CrossRef]

51. Ogada, T.; Werther, J. Combustion characteristics of wet sludge in a fluidized bed: Release and combustion of the volatiles. Fuel 1996, 75, 617-626. [CrossRef]

52. Urciuolo, M.; Solimene, R.; Chirone, R.; Salatino, P. Fluidized bed combustion and fragmentation of wet sewage sludge. Exp. Therm. Fluid Sci. 2012, 43, 97-104. [CrossRef]

53. Folgueras, M.B.; Alonso, M.; Díaz, R.M. Influence of sewage sludge treatment on pyrolysis and combustion of dry sludge. Energy 2013, 55, 426-435. [CrossRef]

54. Werther, J.; Ogada, T. Sewage sludge combustion. Prog. Energy Combust. Sci. 1999, 25, 55-116. [CrossRef]

55. Dennis, J.S.; Lambert, R.J.; Milne, A.J.; Scott, S.A.; Hayhurst, A.N. The kinetics of combustion of chars derived from sewage sludge. Fuel 2005, 84, 117-126. [CrossRef]

56. Cui, H.; Ninomiya, Y.; Masui, M.; Mizukoshi, H.; Sakano, T.; Kanaoka, C. Fundamental Behaviors in Combustion of Raw Sewage Sludge. Energy Fuels 2006, 20, 77-83. [CrossRef]

57. Rong, H.; Wang, T.; Zhou, M.; Wang, H.; Hou, H.; Xue, Y. Combustion Characteristics and Slagging during Co-Combustion of Rice Husk and Sewage Sludge Blends. Energies 2017, 10, 438. [CrossRef]

58. Chen, G.-B.; Chatelier, S.; Lin, H.-T.; Wu, F.-H.; Lin, T.-H. A Study of Sewage Sludge Co-Combustion with Australian Black Coal and Shiitake Substrate. Energies 2018, 11, 3436. [CrossRef]

59. Fytili, D.; Zabaniotou, A. Utilization of sewage sludge in EU application of old and new methods-A review. Renew. Sustain. Energy Rev. 2008, 12, 116-140. [CrossRef]

60. Kijo-Kleczkowska, A.; Środa, K.; Otwinowski, H. Study into Combustion of Sewage Sludge as Energetic Fuel/Badania Spalania Osadów Ściekowych Jako Paliwa Energetycznego. Arch. Min. Sci. 2013, 58, 1085. [CrossRef]

61. Batistella, L.; Silva, V.; Suzin, R.C.; Virmond, E.; Althoff, C.A.; Moreira, R.F.P.M.; José, H.J. Gaseous emissions from sewage sludge combustion in a moving bed combustor. Waste Manag. 2015, 46, 430-439. [CrossRef]

62. Kijo-Kleczkowska, A.; Środa, K.; Kosowska-Golachowska, M.; Musiał, T.; Wolski, K. Combustion of pelleted sewage sludge with reference to coal and biomass. Fuel 2016, 170, 141-160. [CrossRef]

63. Lin, Y.; Liao, Y.; Yu, Z.; Fang, S.; Ma, X. The investigation of co-combustion of sewage sludge and oil shale using thermogravimetric analysis. Thermochim. Acta 2017, 653, 71-78. [CrossRef]

64. Huang, L.; Liu, J.; He, Y.; Sun, S.; Chen, J.; Sun, J.; Chang, K.; Kuo, J.; Ning, X.A. Thermodynamics and kinetics parameters of co-combustion between sewage sludge and water hyacinth in $\mathrm{CO}_{2} / \mathrm{O}_{2}$ atmosphere as biomass to solid biofuel. Bioresour. Technol. 2016, 218, 631-642. [CrossRef]

65. Wang, Z.; Hong, C.; Xing, Y.; Li, Y.; Feng, L.; Jia, M. Combustion behaviors and kinetics of sewage sludge blended with pulverized coal: With and without catalysts. Waste Manag. 2018, 74, 288-296. [CrossRef]

66. Kijo-Kleczkowska, A.; Środa, K.; Kosowska-Golachowska, M.; Musiał, T.; Wolski, K. Experimental research of sewage sludge with coal and biomass co-combustion, in pellet form. Waste Manag. 2016, 53, 165-181. [CrossRef] [PubMed]

67. Deng, S.; Tan, H.; Wang, X.; Yang, F.; Cao, R.; Wang, Z.; Ruan, R. Investigation on the fast co-pyrolysis of sewage sludge with biomass and the combustion reactivity of residual char. Bioresour. Technol. 2017, 239, 302-310. [CrossRef]

68. Niu, X.; Shen, L. Release and transformation of phosphorus in chemical looping combustion of sewage sludge. Chem. Eng. J. 2018, 335, 621-630. [CrossRef]

69. Cheng, X.; Zhang, M.; Wang, Z.; Xu, G.; Ma, C. IR and kinetic study of sewage sludge combustion at different oxygen concentrations. Waste Manag. 2018, 74, 279-287. [CrossRef] [PubMed]

70. Chen, Y.; Wang, T.; Zhou, M.; Hou, H.; Xue, Y.; Wang, H. Rice husk and sewage sludge co-combustion ash: Leaching behavior analysis and cementitious property. Constr. Build. Mater. 2018, 163, 63-72. [CrossRef]

71. Han, X.; Niu, M.; Jiang, X.; Liu, J. Combustion Characteristics of Sewage Sludge in a Fluidized Bed. Ind. Eng. Chem. Res. 2012, 51, 10565-10570. [CrossRef]

72. Hao, Z.; Yang, B.; Jahng, D. Combustion characteristics of biodried sewage sludge. Waste Manag. 2018, 72, 296-305. [CrossRef]

73. Hong, J.; Xu, C.; Hong, J.; Tan, X.; Chen, W. Life cycle assessment of sewage sludge co-incineration in a coal-based power station. Waste Manag. 2013, 33, 1843-1852. [CrossRef] 
74. Morais, J.; Barbosa, R.; Lapa, N.; Mendes, B.; Gulyurtlu, I. Environmental and socio-economic assessment of co-combustion of coal, biomass and non-hazardous wastes in a Power Plant. Resour. Conserv. Recycl. 2011, 55, 1109-1118. [CrossRef]

75. Donatello, S.; Cheeseman, C.R. Recycling and recovery routes for incinerated sewage sludge ash (ISSA): A review. Waste Manag. 2013, 33, 2328-2340. [CrossRef]

76. Magdziarz, A.; Wilk, M. Thermogravimetric study of biomass, sewage sludge and coal combustion. Energy Convers. Manag. 2013, 75, 425-430. [CrossRef]

77. Kirubakaran, V.; Sivaramakrishnan, V.; Nalini, R.; Sekar, T.; Premalatha, M.; Subramanian, P. A review on gasification of biomass. Renew. Sustain. Energy Rev. 2009, 13, 179-186. [CrossRef]

78. Ruiz, J.A.; Juárez, M.C.; Morales, M.P.; Muñoz, P.; Mendívil, M.A. Biomass gasification for electricity generation: Review of current technology barriers. Renew. Sustain. Energy Rev. 2013, 18, 174-183. [CrossRef]

79. Zhang, L.; Xu, C.C.; Champagne, P. Overview of recent advances in thermo-chemical conversion of biomass. Energy Convers. Manag. 2010, 51, 969-982. [CrossRef]

80. Balat, M.; Balat, M.; Kirtay, E.; Balat, H. Main routes for the thermo-conversion of biomass into fuels and chemicals. Part 1: Pyrolysis systems. Energy Convers. Manag. 2009, 50, 3147-3157. [CrossRef]

81. Rollinson, A.N.; Oladejo, J.M. 'Patented blunderings', efficiency awareness, and self-sustainability claims in the pyrolysis energy from waste sector. Resour. Conserv. Recycl. 2019, 141, 233-342. [CrossRef]

82. Alvarez, J.; Amutio, M.; Lopez, G.; Bilbao, J.; Olazar, M. Fast co-pyrolysis of sewage sludge and lignocellulosic biomass in a conical spouted bed reactor. Fuel 2015, 159, 810-818. [CrossRef]

83. Font, R.; Fullana, A.; Conesa, J.A.; Llavador, F. Analysis of the pyrolysis and combustion of different sewage sludges by TG. J. Anal. Appl. Pyrolysis 2001, 58-59, 927-941. [CrossRef]

84. Fonts, I.; Gea, G.; Azuara, M.; Ábrego, J.; Arauzo, J. Sewage sludge pyrolysis for liquid production: A review. Renew. Sustain. Energy Rev. 2012, 16, 2781-2805. [CrossRef]

85. Xu, W.Y.; Wu, D. Comprehensive utilization of the pyrolysis products from sewage sludge. Environ. Technol. 2015, 36, 1731-1744. [CrossRef] [PubMed]

86. Yi, S.; Jang, Y.-C.; An, A.K. Potential for energy recovery and greenhouse gas reduction through waste-to-energy technologies. J. Clean. Prod. 2018, 176, 503-511. [CrossRef]

87. Alvarez, J.; Lopez, G.; Amutio, M.; Artetxe, M.; Barbarias, I.; Arregi, A.; Bilbao, J.; Olazar, M. Characterization of the bio-oil obtained by fast pyrolysis of sewage sludge in a conical spouted bed reactor. Fuel Process. Technol. 2016, 149, 169-175. [CrossRef]

88. Lehto, J.; Oasmaa, A.; Solantausta, Y.; Kytö, M.; Chiaramonti, D. Review of fuel oil quality and combustion of fast pyrolysis bio-oils from lignocellulosic biomass. Appl. Energy 2014, 116, 178-190. [CrossRef]

89. Álvarez, E.A.; Mochón, M.C.; Sánchez, J.C.J.; Rodríguez, M.T. Heavy metal extractable forms in sludge from wastewater treatment plants. Chemosphere 2002, 47, 765-775. [CrossRef]

90. Shen, L.; Zhang, D.-K. An experimental study of oil recovery from sewage sludge by low-temperature pyrolysis in a fluidised-bed. Fuel 2003, 82, 465-472. [CrossRef]

91. Pedroza, M.M.; Sousa, J.F.; Vieira, G.E.G.; Bezerra, M.B.D. Characterization of the products from the pyrolysis of sewage sludge in 1kg/h rotating cylinder reactor. J. Anal. Appl. Pyrolysis 2014, 105, 108-115. [CrossRef]

92. Park, H.J.; Heo, H.S.; Park, Y.-K.; Yim, J.-H.; Jeon, J.-K.; Park, J.; Ryu, C.; Kim, S.-S. Clean bio-oil production from fast pyrolysis of sewage sludge: Effects of reaction conditions and metal oxide catalysts. Bioresour. Technol. 2010, 101, S83-S85. [CrossRef] [PubMed]

93. Domínguez, A.; Menéndez, J.A.; Pis, J.J. Hydrogen rich fuel gas production from the pyrolysis of wet sewage sludge at high temperature. J. Anal. Appl. Pyrolysis 2006, 77, 127-132. [CrossRef]

94. Xie, Q.; Peng, P.; Liu, S.; Min, M.; Cheng, Y.; Wan, Y.; Li, Y.; Lin, X.; Liu, Y.; Chen, P.; et al. Fast microwave-assisted catalytic pyrolysis of sewage sludge for bio-oil production. Bioresour. Technol. 2014, 172, 162-168. [CrossRef] [PubMed]

95. Lin, K.-H.; Lai, N.; Zeng, J.-Y.; Chiang, H.-L. Temperature influence on product distribution and characteristics of derived residue and oil in wet sludge pyrolysis using microwave heating. Sci. Total Environ. 2017, 584-585, 1248-1255. [CrossRef] [PubMed]

96. Gao, N.; Li, J.; Qi, B.; Li, A.; Duan, Y.; Wang, Z. Thermal analysis and products distribution of dried sewage sludge pyrolysis. J. Anal. Appl. Pyrolysis 2014, 105, 43-48. [CrossRef] 
97. Jin, J.; Li, Y.; Zhang, J.; Wu, S.; Cao, Y.; Liang, P.; Zhang, J.; Wong, M.H.; Wang, M.; Shan, S.; et al. Influence of pyrolysis temperature on properties and environmental safety of heavy metals in biochars derived from municipal sewage sludge. J. Hazard. Mater. 2016, 320, 417-426. [CrossRef] [PubMed]

98. Gao, N.; Quan, C.; Liu, B.; Li, Z.; Wu, C.; Li, A. Continuous Pyrolysis of Sewage Sludge in a Screw-Feeding Reactor: Products Characterization and Ecological Risk Assessment of Heavy Metals. Energy Fuels 2017, 31, 5063-5072. [CrossRef]

99. Zhou, J.; Liu, S.; Zhou, N.; Fan, L.; Zhang, Y.; Peng, P.; Anderson, E.; Ding, K.; Wang, Y.; Liu, Y.; et al. Development and application of a continuous fast microwave pyrolysis system for sewage sludge utilization. Bioresour. Technol. 2018, 256, 295-301. [CrossRef]

100. Zhuang, L.; Zhou, S.; Wang, Y.; Liu, Z.; Xu, R. Cost-effective production of Bacillus thuringiensis biopesticides by solid-state fermentation using wastewater sludge: Effects of heavy metals. Bioresour. Technol. 2011, 102, 4820-4826. [CrossRef]

101. Longo, S.; Katsou, E.; Malamis, S.; Frison, N.; Renzi, D.; Fatone, F. Recovery of volatile fatty acids from fermentation of sewage sludge in municipal wastewater treatment plants. Bioresour. Technol. 2015, 175, 436-444. [CrossRef]

102. Chen, H.; Chen, D.; Hong, L. Influences of activation agent impregnated sewage sludge pyrolysis on emission characteristics of volatile combustion and De-NOx performance of activated char. Appl. Energy 2015, 156, 767-775. [CrossRef]

103. Chen, T.; Zhang, Y.; Wang, H.; Lu, W.; Zhou, Z.; Zhang, Y.; Ren, L. Influence of pyrolysis temperature on characteristics and heavy metal adsorptive performance of biochar derived from municipal sewage sludge. Bioresour. Technol. 2014, 164, 47-54. [CrossRef]

104. Park, E.-S.; Kang, B.-S.; Kim, J.-S. Recovery of Oils with High Caloric Value and Low Contaminant Content by Pyrolysis of Digested and Dried Sewage Sludge Containing Polymer Flocculants. Energy Fuels 2008, 22, 1335-1340. [CrossRef]

105. Pokorna, E.; Postelmans, N.; Jenicek, P.; Schreurs, S.; Carleer, R.; Yperman, J. Study of bio-oils and solids from flash pyrolysis of sewage sludges. Fuel 2009, 88, 1344-1350. [CrossRef]

106. Lee, Y.-E.; Kim, I.-T.; Yoo, Y.-S. Stabilization of High-Organic-Content Water Treatment Sludge by Pyrolysis. Energies 2018, 11, 3292. [CrossRef]

107. Kim, Y.; Parker, W. A technical and economic evaluation of the pyrolysis of sewage sludge for the production of bio-oil. Bioresour. Technol. 2008, 99, 1409-1416. [CrossRef] [PubMed]

108. Ischia, M.; Maschio, R.D.; Grigiante, M.; Baratieri, M. Clay-sewage sludge co-pyrolysis. A TG-MS and Py-GC study on potential advantages afforded by the presence of clay in the pyrolysis of wastewater sewage sludge. Waste Manag. 2011, 31, 71-77. [CrossRef]

109. Fonts, I.; Juan, A.; Gea, G.; Murillo, M.B.; Sánchez, J.L. Sewage Sludge Pyrolysis in Fluidized Bed, 1: Influence of Operational Conditions on the Product Distribution. Ind. Eng. Chem. Res. 2008, 47, 5376-5385. [CrossRef]

110. Ma, R.; Sun, S.; Geng, H.; Fang, L.; Zhang, P.; Zhang, X. Study on the characteristics of microwave pyrolysis of high-ash sludge, including the products, yields, and energy recovery efficiencies. Energy 2018, 144, 515-525. [CrossRef]

111. Huang, Y.-F.; Shih, C.-H.; Chiueh, P.-T.; Lo, S.-L. Microwave co-pyrolysis of sewage sludge and rice straw. Energy 2015, 87, 638-644. [CrossRef]

112. Chen, G.-B.; Li, J.-W.; Lin, H.-T.; Wu, F.-H.; Chao, Y.-C. A Study of the Production and Combustion Characteristics of Pyrolytic Oil from Sewage Sludge Using the Taguchi Method. Energies 2018, 11, 2260. [CrossRef]

113. Roche, E.; de Andrés, J.M.; Narros, A.; Rodríguez, M.E. Air and air-steam gasification of sewage sludge. The influence of dolomite and throughput in tar production and composition. Fuel 2014, 115, 54-61. [CrossRef]

114. Damartzis, T.; Zabaniotou, A. Thermochemical conversion of biomass to second generation biofuels through integrated process design-A review. Renew. Sustain. Energy Rev. 2011, 15, 366-378. [CrossRef]

115. Ferrasse, J.H.; Seyssiecq, I.; Roche, N. Thermal Gasification: A Feasible Solution for Sewage Sludge Valorisation? Chem. Eng. Technol. 2003, 26, 941-945. [CrossRef]

116. Sikarwar, V.S.; Zhao, M.; Clough, P.; Yao, J.; Zhong, X.; Memon, M.Z.; Shah, N.; Anthony, E.J.; Fennell, P.S. An overview of advances in biomass gasification. Energy Environ. Sci. 2016, 9, 2939-2977. [CrossRef] 
117. Werle, S. Gasification of a Dried Sewage Sludge in a Laboratory Scale Fixed Bed Reactor. Energies 2015, 8, 8562-8572. [CrossRef]

118. Dogru, M.; Midilli, A.; Howarth, C.R. Gasification of sewage sludge using a throated downdraft gasifier and uncertainty analysis. Fuel Process. Technol. 2002, 75, 55-82. [CrossRef]

119. Midilli, A.; Dogru, M.; Howarth, C.R.; Ling, M.J.; Ayhan, T. Combustible gas production from sewage sludge with a downdraft gasifier. Energy Convers. Manag. 2001, 42, 157-172. [CrossRef]

120. McKendry, P. Energy production from biomass (part 3): Gasification technologies. Bioresour. Technol. 2002, 83, 55-63. [CrossRef]

121. Nilsson, S.; Gómez-Barea, A.; Cano, D.F. Gasification reactivity of char from dried sewage sludge in a fluidized bed. Fuel 2012, 92, 346-353. [CrossRef]

122. Mun, T.-Y.; Kang, B.-S.; Kim, J.-S. Production of a Producer Gas with High Heating Values and Less Tar from Dried Sewage Sludge through Air Gasification Using a Two-Stage Gasifier and Activated Carbon. Energy Fuels 2009, 23, 3268-3276. [CrossRef]

123. De Andrés, J.M.; Narros, A.; Rodríguez, M.E. Air-steam gasification of sewage sludge in a bubbling bed reactor: Effect of alumina as a primary catalyst. Fuel Process. Technol. 2011, 92, 433-440. [CrossRef]

124. Arjharn, W.; Hinsui, T.; Liplap, P.; Raghavan, G.S.V. Evaluation of an Energy Production System from Sewage Sludge Using a Pilot-Scale Downdraft Gasifier. Energy Fuels 2013, 27, 229-236. [CrossRef]

125. Seggiani, M.; Puccini, M.; Raggio, G.; Vitolo, S. Effect of sewage sludge content on gas quality and solid residues produced by cogasification in an updraft gasifier. Waste Manag. 2012, 32, 1826-1834. [CrossRef]

126. Choi, Y.-K.; Ko, J.-H.; Kim, J.-S. A new type three-stage gasification of dried sewage sludge: Effects of equivalence ratio, weight ratio of activated carbon to feed, and feed rate on gas composition and tar, NH3, and $\mathrm{H}_{2} \mathrm{~S}$ removal and results of approximately $5 \mathrm{~h}$ gasification. Energy 2017, 118, 139-146. [CrossRef]

127. Mun, T.-Y.; Kim, J.-O.; Kim, J.-W.; Kim, J.-S. Influence of operation conditions and additives on the development of producer gas and tar reduction in air gasification of construction woody wastes using a two-stage gasifier. Bioresour. Technol. 2011, 102, 7196-7203. [CrossRef]

128. Manyà, J.J.; Aznar, M.; Sánchez, J.L.; Arauzo, J.; Murillo, M.B. Further Experiments on Sewage Sludge Air Gasification: Influence of the Nonstationary Period on the Overall Results. Industrial \& Engineering Chemistry Research 2006, 45, 7313-7320. [CrossRef]

129. Nipattummakul, N.; Ahmed, I.I.; Kerdsuwan, S.; Gupta, A.K. Hydrogen and syngas production from sewage sludge via steam gasification. Int. J. Hydrogen Energy 2010, 35, 11738-11745. [CrossRef]

130. Mun, T.-Y.; Kim, J.-W.; Kim, J.-S. Air gasification of dried sewage sludge in a two-stage gasifier: Part 1. The effects and reusability of additives on the removal of tar and hydrogen production. Int. J. Hydrogen Energy 2013, 38, 5226-5234. [CrossRef]

131. García, G.; Monzón, A.; Bimbela, F.; Sánchez, J.L.; Ábrego, J. Desulfurization and Catalytic Gas Cleaning in Fluidized-Bed Co-gasification of Sewage Sludge-Coal Blends. Energy Fuels 2013, 27, 2846-2856. [CrossRef]

132. De Andrés, J.M.; Narros, A.; Rodríguez, M.E. Behaviour of dolomite, olivine and alumina as primary catalysts in air-steam gasification of sewage sludge. Fuel 2011, 90, 521-527. [CrossRef]

133. Choi, Y.-K.; Ko, J.-H.; Kim, J.-S. Gasification of dried sewage sludge using an innovative three-stage gasifier: Clean and $\mathrm{H}_{2}$-rich gas production using condensers as the only secondary tar removal apparatus. Fuel 2018, 216, 810-817. [CrossRef]

134. Chen, S.; Sun, Z.; Zhang, Q.; Hu, J.; Xiang, W. Steam gasification of sewage sludge with $\mathrm{CaO}$ as $\mathrm{CO}_{2}$ sorbent for hydrogen-rich syngas production. Biomass Bioenergy 2017, 107, 52-62. [CrossRef]

135. Cao, J.-P.; Huang, X.; Zhao, X.-Y.; Wang, B.-S.; Meesuk, S.; Sato, K.; Wei, X.-Y.; Takarada, T. Low-temperature catalytic gasification of sewage sludge-derived volatiles to produce clean $\mathrm{H}_{2}$-rich syngas over a nickel loaded on lignite char. Int. J. Hydrogen Energy 2014, 39, 9193-9199. [CrossRef]

136. Lee, K.-W.; Lee, W.C.; Lee, H.J.; Dong, J.I. Gasification characteristics of sewage sludge combined with wood biomass. J. Mater. Cycles Waste Manag. 2014, 16, 642-649. [CrossRef]

137. Aznar, M.; Manyà, J.J.; García, G.; Sánchez, J.L.; Murillo, M.B. Influence of Freeboard Temperature, Fluidization Velocity, and Particle Size on Tar Production and Composition during the Air Gasification of Sewage Sludge. Energy Fuels 2008, 22, 2840-2850. [CrossRef]

138. Manyà, J.J.; Sánchez, J.L.; Gonzalo, A.; Arauzo, J. Air Gasification of Dried Sewage Sludge in a Fluidized Bed: Effect of the Operating Conditions and In-Bed Use of Alumina. Energy Fuels 2005, 19, 629-636. [CrossRef] 
139. Lee, U.; Dong, J.; Chung, J.N. Experimental investigation of sewage sludge solid waste conversion to syngas using high temperature steam gasification. Energy Convers. Manag. 2018, 158, 430-436. [CrossRef]

140. Freda, C.; Cornacchia, G.; Romanelli, A.; Valerio, V.; Grieco, M. Sewage sludge gasification in a bench scale rotary kiln. Fuel 2018, 212, 88-94. [CrossRef]

141. Campoy, M.; Gómez-Barea, A.; Ollero, P.; Nilsson, S. Gasification of wastes in a pilot fluidized bed gasifier. Fuel Process. Technol. 2014, 121, 63-69. [CrossRef]

142. Reed, G.P.; Paterson, N.P.; Zhuo, Y.; Dugwell, D.R.; Kandiyoti, R. Trace Element Distribution in Sewage Sludge Gasification: Source and Temperature Effects. Energy Fuels 2005, 19, 298-304. [CrossRef]

143. Sharma, A.K. Experimental investigations on a $20 \mathrm{kWe}$, solid biomass gasification system. Biomass Bioenergy 2011, 35, 421-428. [CrossRef]

144. Peng, L.; Wang, Y.; Lei, Z.; Cheng, G. Co-gasification of wet sewage sludge and forestry waste in situ steam agent. Bioresour. Technol. 2012, 114, 698-702. [CrossRef] [PubMed]

145. Zhang, Q.; Liu, H.; Li, W.; Xu, J.; Liang, Q. Behavior of Phosphorus during Co-gasification of Sewage Sludge and Coal. Energy Fuels 2012, 26, 2830-2836. [CrossRef]

146. Manara, P.; Zabaniotou, A. Towards sewage sludge based biofuels via thermochemical conversion-A review. Renew. Sustain. Energy Rev. 2012, 16, 2566-2582. [CrossRef]

147. Kistler, R.C.; Widmer, F.; Brunner, P.H. Behavior of chromium, nickel, copper, zinc, cadmium, mercury, and lead during the pyrolysis of sewage sludge. Environ. Sci. Technol. 1987, 21, 704-708. [CrossRef] [PubMed]

148. Elled, A.-L.; Åmand, L.-E.; Leckner, B.; Andersson, B.-Å. The fate of trace elements in fluidised bed combustion of sewage sludge and wood. Fuel 2007, 86, 843-852. [CrossRef]

149. Shen, Y.; Yoshikawa, K. Recent progresses in catalytic tar elimination during biomass gasification or pyrolysis-A review. Renew. Sustain. Energy Rev. 2013, 21, 371-392. [CrossRef]

150. Campoy, M.; Gómez-Barea, A.; Fuentes-Cano, D.; Ollero, P. Tar Reduction by Primary Measures in an Autothermal Air-Blown Fluidized Bed Biomass Gasifier. Ind. Eng. Chem. Res. 2010, 49, 11294-11301. [CrossRef]

151. Smoliński, A.; Howaniec, N.; Bąk, A. Utilization of Energy Crops and Sewage Sludge in the Process of Co-Gasification for Sustainable Hydrogen Production. Energies 2018, 11, 809. [CrossRef]

(C) 2018 by the authors. Licensee MDPI, Basel, Switzerland. This article is an open access article distributed under the terms and conditions of the Creative Commons Attribution (CC BY) license (http://creativecommons.org/licenses/by/4.0/). 